\title{
Methods and Basic Data from Mass-Loading Studies in American Fork, October 1999, and Mary Ellen Gulch, Utah, September 2000
}

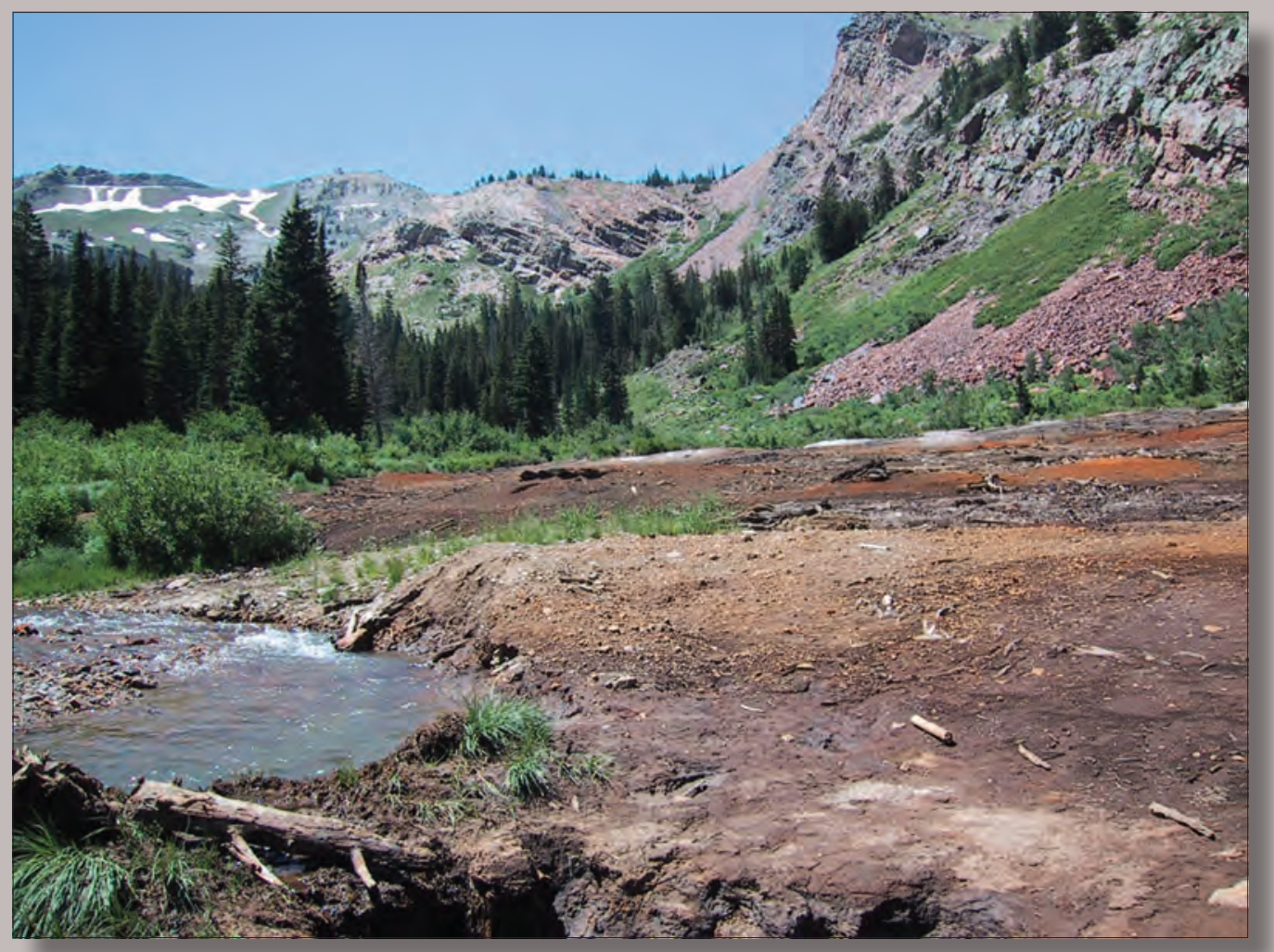

Prepared in cooperation with the U.S. Forest Service

Data Series 443

U.S. Department of the Interior

U.S. Geological Survey 
Cover: Photograph of iron bog in upper American Fork Canyon, looking northeast toward Mineral Basin. American Fork runs to the left and receives drainage from the bog. Photo by Briant Kimball taken on July 26, 2005. 


\section{Methods and Basic Data from Mass-Loading Studies in American Fork, October 1999, and Mary Ellen Gulch, Utah, September 2000}

By Briant A. Kimball, Robert L. Runkel, and Linda J. Gerner

Prepared in cooperation with the U.S. Forest Service

Data Series 443 


\title{
U.S. Department of the Interior \\ KEN SALAZAR, Secretary
}

\author{
U.S. Geological Survey \\ Suzette M. Kimball, Acting Director
}

U.S. Geological Survey, Reston, Virginia: 2009

For product and ordering information:

World Wide Web: http://www.usgs.gov/pubprod

Telephone: 1-888-ASK-USGS

For more information on the USGS--the Federal source for science about the Earth, its natural and living resources, natural hazards, and the environment:

World Wide Web: http://www.usgs.gov

Telephone: 1-888-ASK-USGS

Any use of trade, product, or firm names is for descriptive purposes only and does not imply endorsement by the U.S. Government.

Although this report is in the public domain, permission must be secured from the individual copyright owners to reproduce any copyrighted materials contained within this report.

Suggested citation:

Kimball, B.A., Runkel, R.L., and Gerner, L.J., 2009, Methods and basic data from mass-loading studies in American Fork, October 1999, and Mary Ellen Gulch, Utah, September 2000: U.S. Geological Survey Data Series 443, 33p.;

Available at http://pubs.usgs.gov/ds/443. 


\section{Contents}

Abstract
Introduction.
Methods
$\quad$ Sracer Injections and Stream Discharge
Constituent Loads
Results of Mass-Loading Studies
Chemical Analysis of Synoptic Samples
References Cited

\section{Figures}

1. Map showing locations of stream and inflow sampling sites and principal mines in American Fork and Mary Ellen Gulch, Utah..

2. Graph showing (A) mass-loading profiles for aluminum and (B) change in aluminum load for individual stream segments, including unsampled inflow load, American Fork, Utah, October 1999

3. Graph showing (A) mass-loading profiles for iron and (B) change in iron load for individual stream segments, including unsampled inflow load, American Fork, Utah, October 1999

4. Graph showing (A) mass-loading profiles for manganese and (B) change in manganese load for individual stream segments, including unsampled inflow load, American Fork, Utah, October 1999

5. Graph showing (A) mass-loading profiles for zinc and (B) change in zinc load for individual stream segments, including unsampled inflow load, American Fork, Utah, October 1999

6. Graph showing $(A)$ mass-loading profiles for aluminum and $(B)$ change in aluminum load for individual stream segments, including unsampled inflow load, Mary Ellen Gulch, Utah, September 2000

7. Graph showing $(A)$ mass-loading profiles for iron and $(B)$ change in iron load for individual stream segments, including unsampled inflow load, Mary Ellen Gulch, Utah, September 2000.

8. Graph showing (A) mass-loading profiles for copper and (B) change in copper load for individual stream segments, including unsampled inflow load, Mary Ellen Gulch, Utah, September 2000.

9. Graph showing (A) mass-loading profiles for manganese and (B) change in manganese load for individual stream segments, including unsampled inflow load, Mary Ellen Gulch, Utah, September 2000

10. Graph showing (A) mass-loading profiles for zinc and (B) change in zinc load for individual stream segments, including unsampled inflow load, Mary Ellen Gulch, Utah, September 2000 


\section{Tables}

1. Source, site description, $\mathrm{pH}$, calculated discharge, and tracer concentrations for synoptic samples from American Fork, October 1999, and Mary Ellen Gulch, Utah, September 2000

2. Chemical analyses for major ions in water samples from American Fork, October 1999, and Mary Ellen Gulch, Utah, September 2000

3. Chemical analyses of trace elements in water samples from American Fork, October 1999, and Mary Ellen Gulch, Utah, September 2000

4. Method detection limits and relative standard deviation of quality-assurance samples 


\section{Conversion Factors, Datums, and Abbreviated Water-Quality Units}

\begin{tabular}{lcl}
\hline Multiply & By & To obtain \\
\hline & Length & \\
\hline micrometer $(\mu \mathrm{m})$ & 0.03937 & inch (in.) \\
meter $(\mathrm{m})$ & 3.281 & foot (ft) \\
\hline & Flow rate & \\
\hline liter per second $(\mathrm{L} / \mathrm{s})$ & 15.85 & gallon per minute (gal/min) \\
\hline & Mass flow & \\
\hline kilogram per day $(\mathrm{kg} / \mathrm{d})$ & 1,233 & pound per day $(\mathrm{lb} / \mathrm{d})$ \\
\hline
\end{tabular}

Temperature in degrees Celsius $\left({ }^{\circ} \mathrm{C}\right)$ may be converted to degrees Fahrenheit $\left({ }^{\circ} \mathrm{F}\right)$ as follows:

$$
{ }^{\circ} \mathrm{F}=\left(1.8 \times{ }^{\circ} \mathrm{C}\right)+32 .
$$

Temperature in degrees Fahrenheit $\left({ }^{\circ} \mathrm{F}\right)$ may be converted to degrees Celsius $\left({ }^{\circ} \mathrm{C}\right)$ as follows:

$$
{ }^{\circ} \mathrm{C}=\left({ }^{\circ} \mathrm{F}-32\right) / 1.8 \text {. }
$$

Vertical coordinate information is referenced to the North American Vertical Datum of 1988 (NAVD 88); horizontal coordinate information is referenced to the North American Datum of 1983 (NAD 83). Altitude, as used in this report, refers to distance above the vertical datum.

Specific conductance is given in microsiemens per centimeter at 25 degrees Celsius $(\mu \mathrm{S} / \mathrm{cm}$ at $25^{\circ} \mathrm{C}$ ). Concentrations of chemical constituents in water are reported either in milligrams per liter (mg/L) or micrograms per liter ( $\mu \mathrm{g} / \mathrm{L})$. 


\title{
Methods and Basic Data from Mass-Loading Studies in American Fork, October 1999, and Mary Ellen Gulch, Utah, September 2000
}

\author{
By Briant A. Kimball, Robert L. Runkel, and Linda J. Gerner
}

\section{Abstract}

Land-management agencies are faced with decisions about remediation in streams affected by mine drainage. In support of the U.S. Forest Service, for the Uinta National Forest, the U.S. Geological Survey conducted mass-loading studies in American Fork and Mary Ellen Gulch, Utah. Synoptic samples were collected along a 10,000-meter study reach in American Fork and 4,500-meter reach in Mary Ellen Gulch. Tracer-injection methods were combined with synoptic sampling methods to evaluate discharge and mass loading. This data series report presents the results of chemical analyses of these samples and provides the equations used to calculate discharge from tracer concentrations and loads from discharge and concentrations of the constituents. The detailed information from these studies will facilitate the preparation of interpretive reports and discussions with stakeholder groups. Data presented include detailed locations of the sampling sites, results of chemical analyses, and graphs of mass-loading profiles for major and trace elements in American Fork and Mary Ellen Gulch. Ultrafiltration was used to define filtered concentrations, and total-recoverable concentrations were measured on unfiltered samples.

\section{Introduction}

Mass-loading studies were carried out by the U.S. Geological Survey to support the U.S. Forest Service in planning remediation in American Fork, Utah. The mass-loading studies combined two well-established techniques. First, a conservative tracer was injected to estimate discharge by dilution of the tracer along a 10,000-m study reach in American Fork and a 4,500-m study reach in Mary Ellen Gulch. Second, spatially detailed data derived from synoptic samples from the streams and inflows were used to complement the discharge data and provide the information to calculate changes in loading of major and trace elements in these streams.
The purpose of this data series report is to provide detailed information from these studies to facilitate the preparation of interpretive reports and discussions with stakeholder groups. It includes detailed locations of the sampling sites, results of chemical analyses, and graphs of mass-loading profiles for selected metals.

\section{Methods}

Tracer-injection studies have been used to provide a catchment-scale context for the quantification of metal loads from abandoned and inactive mines. Together with geologic and biologic studies, tracer-injection studies provide much of the information needed to make science-based decisions for a catchment (Buxton and others, 1997). The massloading approach used in this report addresses the problem of solute source determination (Kimball and others, 2002). The approach is based on two well-established techniques: the tracer-dilution method (Kilpatrick and Cobb, 1985) and synoptic sampling (Bencala and McKnight, 1987). The tracer-dilution method provides estimates of stream discharge that are in turn, used to quantify the amount of tributary and groundwater inflow entering the stream in a given stream segment. Synoptic sampling provides a spatially detailed profile of water chemistry along the study reach. It also defines the range of concentrations among inflows that influence the stream profile. When used together, these techniques provide a description of a catchment that quantifies stream discharge and concentrations of constituents that may then be used to determine mass loading of chemical constituents associated with various sources of surface and ground water. Methods used to support the mass-loading approach to catchment studies are detailed in several publications. Applying tracer-dilution methods to mine drainage was developed in studies of St. Kevin Gulch, Colorado (Broshears and others, 1993; Kimball and others, 1994). The general approach is described and applied to a heavily mined and altered catchment in Cement Creek, Colorado, by Kimball and others (2002). Equations to 
evaluate loading were used to contrast mined and unmined areas along the Red River, New Mexico (Kimball and others, 2006a). A much smaller-scale application identified particular hydrogeologic connections through fault shear zones between a stream and mine pit lakes near Strawberry Creek, South Dakota (Kimball and others, 2006b).

This study was undertaken during low-flow conditions in October 1999 and September 2000. Applying the tracerdilution method to low-flow conditions provides a focus on metal sources that enter the stream continuously, but does not address transient, short-term loading that can result from storm or snowmelt runoff. A critical step in this approach was to walk the entire study reach and identify visible inflows and areas of likely ground-water inflow. Stream sampling sites were located upstream and downstream of these inflows and in locations that appeared to bracket areas of potential ground-water inflow (fig. 1). These areas were identified during the stream reconnaissance by observing changes in vegetation, geomorphologic controls, and geologic structure. The intent of placing stream-sampling sites downstream from visible inflows was to capture the visible tributary inflow and any additional subsurface inflow with the tracer dilution. At this level of spatial detail in a watershed, changes in stream chemistry and discharge between stream sampling sites reflect a net metal load for specific segments, but the loads cannot always be attributed to specific sources. Effects of sources on the stream, however, may be characterized by synoptic sampling. Distance along the study reach was measured from each tracer-injection site; both injection sites were assigned a distance of $0 \mathrm{~m}$ in the individual streams, providing an ordinate for the study. Each stream and inflow site is referred to by the downstream distance from the injection site in either American Fork or Mary Ellen Gulch (fig. 1).

\section{Tracer Injections and Stream Discharge}

Quantifying discharge in mountain streams by the traditional velocity-area method (Rantz, 1982) can be compromised by the roughness of the streambed and the variability caused by pools and riffles (Jarrett, 1992). Furthermore, a substantial percentage of stream water may flow through porous areas of the streambed as hyporheic flow (Zellweger and others, 1989). Measuring discharge using the velocity-area method does not account for flow through the hyporheic zone, and therefore, discharge estimates based on the velocity-area method may result in an underestimate of metal loads (Zellweger and others, 1989). Another limitation of the velocity-area method for the characterization of metal loads is the time limit it may place on the number of sites that can be measured in one day. In some studies, as many as 60 in-stream samples have been collected during a single day to characterize stream and inflow chemistry. Measuring velocity-area discharge in conjunction with collecting samples at so many sites can be problematic, if not impossible. An alternative means of estimating discharge used in our study is the tracer-dilution method (Bencala and others, 1990; Kilpatrick and Cobb, 1985). The focus of the present study was on metal loading; a detailed discussion of quantifying discharge, which is an important part of the mass-loading study, can be found in one of the studies cited above.

\section{Synoptic Sampling and Analytical Methods}

Instream concentrations of metals indicate where the stream and the aquatic ecosystem are most affected by metal sources, but those concentrations result from the greatest inflow loads, not necessarily from the highest inflow concentrations. Synoptic sampling gives a spatially intensive "snapshot" of chemistry and discharge so that instream loads can be quantified. Ideally, samples at all the sampling locations would be collected simultaneously, providing an instantaneous, truly synoptic description of stream water quality along the study reach. Personnel limitations generally preclude this, but samples were collected over a relatively short time period (less than 8 hours) to minimize the effect of transient conditions, such as diurnal flow variations.

Stream and inflow samples were collected at the predetermined locations, beginning at the downstream end of the study reach and ending upstream of the tracer-injection site (table 1). This downstream to upstream sampling order was followed in order to avoid disturbing the streambed before sampling. Inflow and stream sites that were considered well mixed were sampled using grab techniques. Sites that were not well mixed, particularly downstream from tributaries, were sampled by equal width integration (Ward and Harr, 1990). Water temperature was measured on site, and water samples were transported to a central field location for further processing. Samples were transported to the central location in dark plastic bags to keep out the sunlight and prevent changes in iron speciation. Samples were divided into several 125-mL bottles according to different treatments given at the central processing location: a raw (unfiltered) unacidified sample (RU), a raw acidified sample (RA), a filtered unacidified sample (FU), a $0.45-\mu \mathrm{m}$ filtered acidified sample (FA), and an ultra-filtered, acidified (UFA) sample was obtained using a 10,000 Dalton tangential-flow filtration device. The UFA sample was used to measure a more truly dissolved concentration than the FA sample. The need for ultrafiltration comes from the nature of $\mathrm{Al}$ and $\mathrm{Fe}$ colloids that can range in size from a nanometer to tenths of micrometers. These colloids, and metals associated with them, can pass through a $0.45-\mu \mathrm{m}$ filter (Kimball and others, 1995). When these samples are acidified, the $\mathrm{Al}$ and $\mathrm{Fe}$ colloidal material dissolves and is mistakenly measured as "dissolved” $\mathrm{Al}$ or Fe.

Anomalously high concentrations of $\mathrm{Zn}$ were noted in a few UFA samples. The high Zn concentration likely was a result of contamination caused by brass fittings contacting the tangential-flow filtration apparatus. The high Zn concentrations in UFA samples were replaced by the corresponding Zn concentrations in the FA sample. 


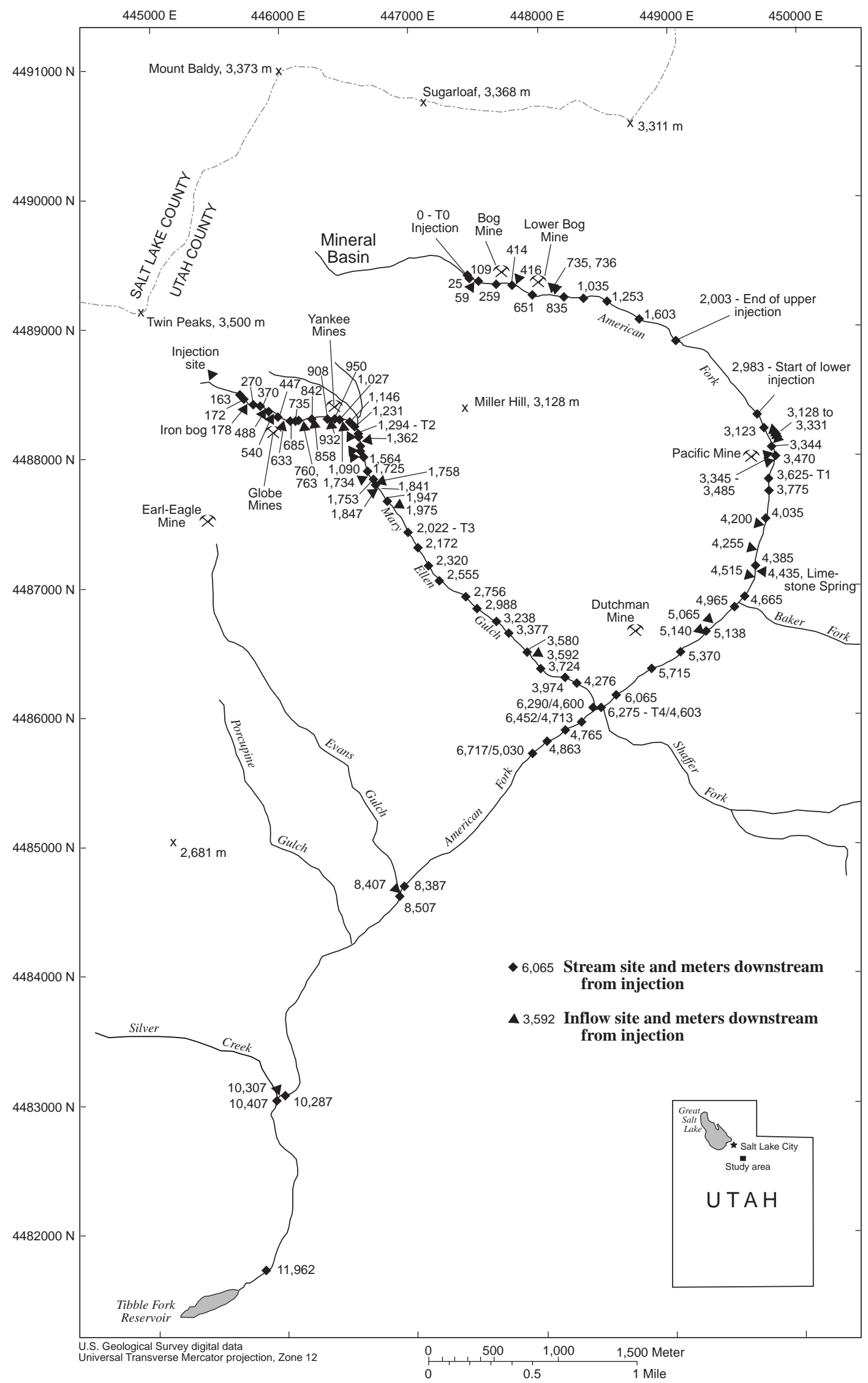

Figure 1. Locations of stream and inflow sampling sites and principal mines in American Fork and Mary Ellen Gulch, Utah. 
Table 1. Source, site description, $\mathrm{pH}$, calculated discharge, and tracer concentrations for synoptic samples from American Fork, October 1999, and Mary Ellen Gulch, Utah, September 2000.

[Distance is from tracer-injection point. Source: S, stream; RBI, right-bank inflow; LBI, left-bank inflow. Easting and Northing, all points Universal Transmercator, Zone 12 north. m, meter; L/s, liters per second; mg/L, milligram per liter; $\mathrm{Cl}$, chloride; $\mathrm{Br}$, bromide, <, less than; NM, not measured]

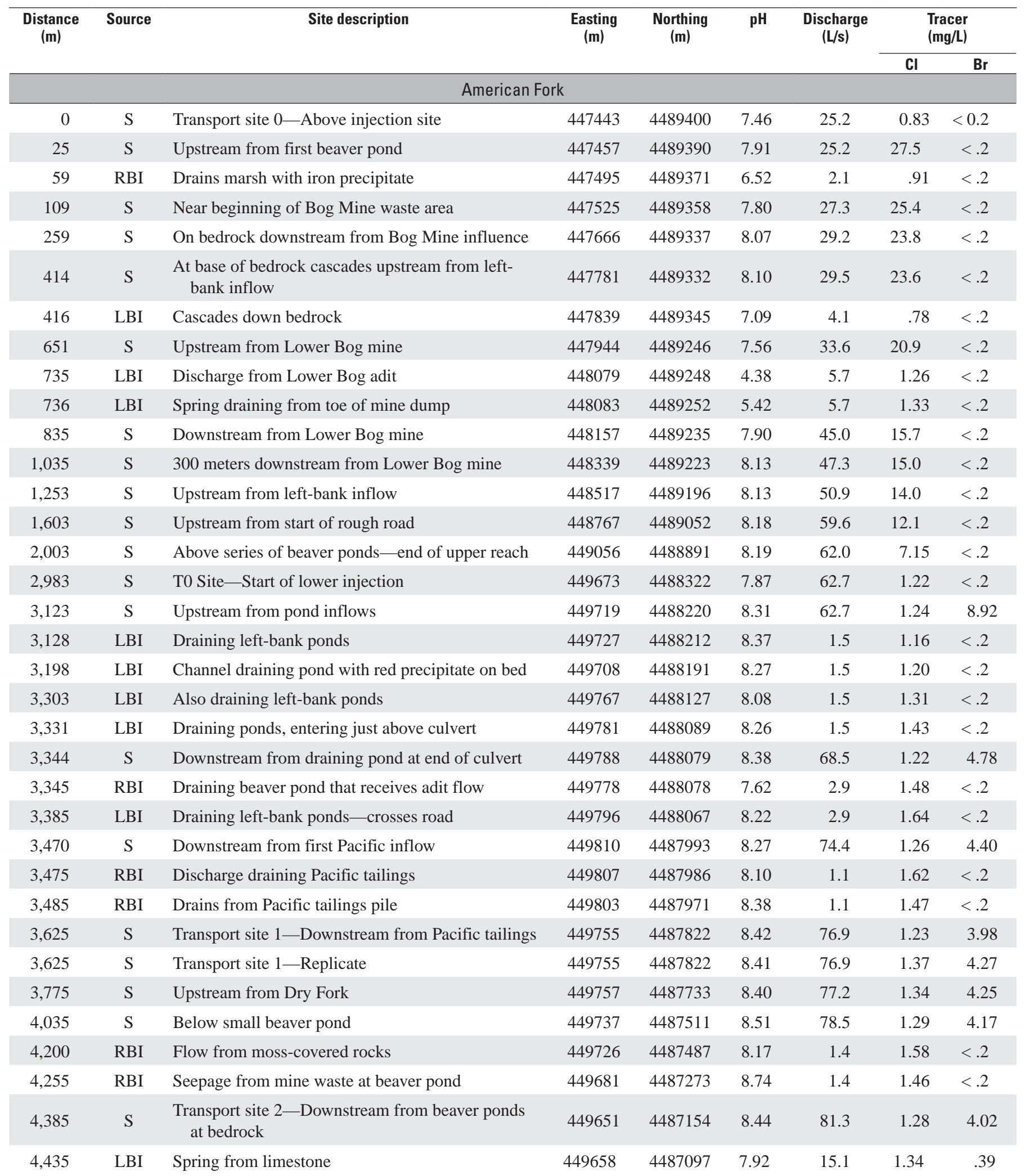


Table 1. Source, site description, $\mathrm{pH}$, calculated discharge, and tracer concentrations for synoptic samples from American Fork, October 1999, and Mary Ellen Gulch, Utah, September 2000.-Continued

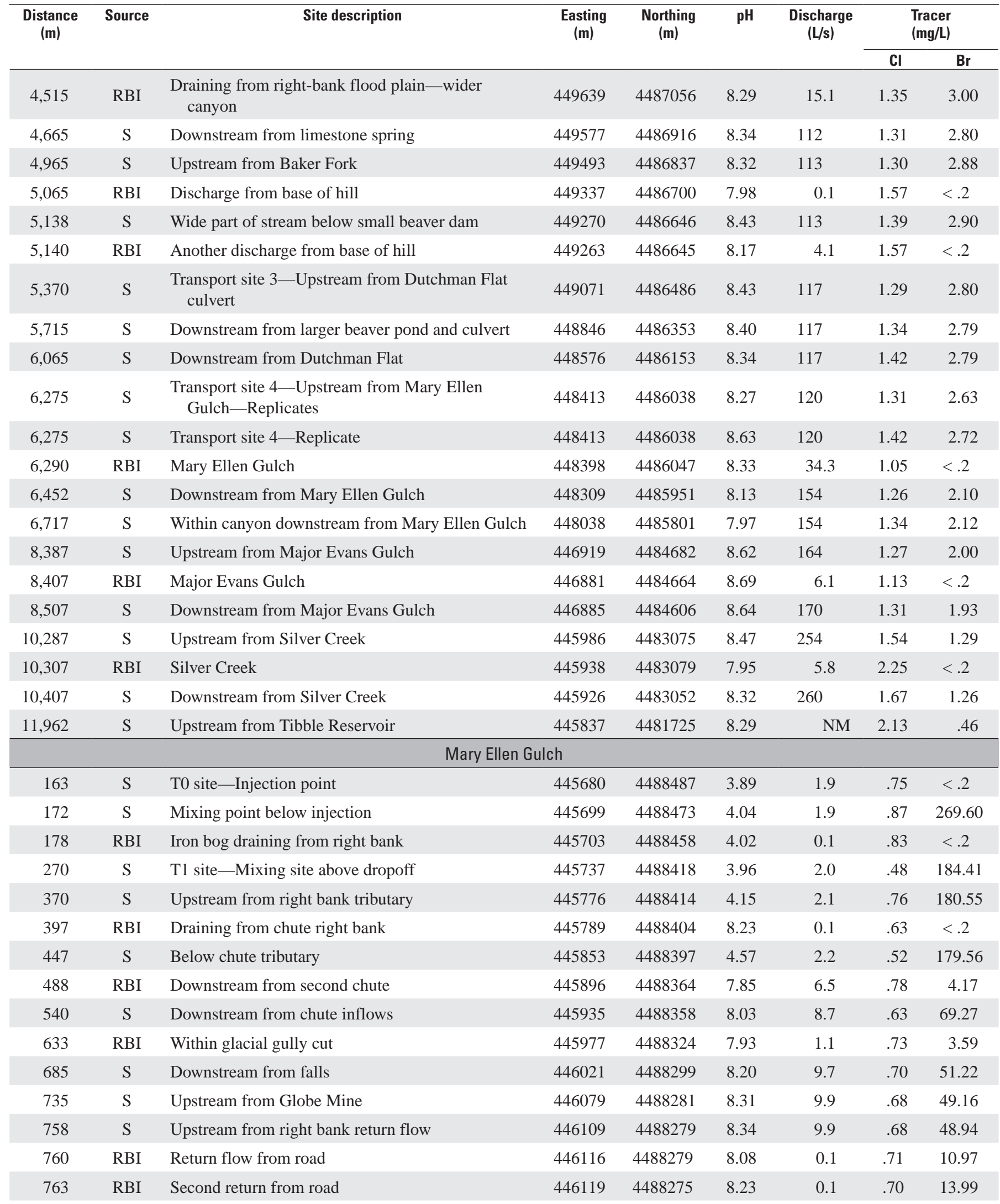


Table 1. Source, site description, pH, calculated discharge, and tracer concentrations for synoptic samples from American Fork, October 1999, and Mary Ellen Gulch, Utah, September 2000.-Continued

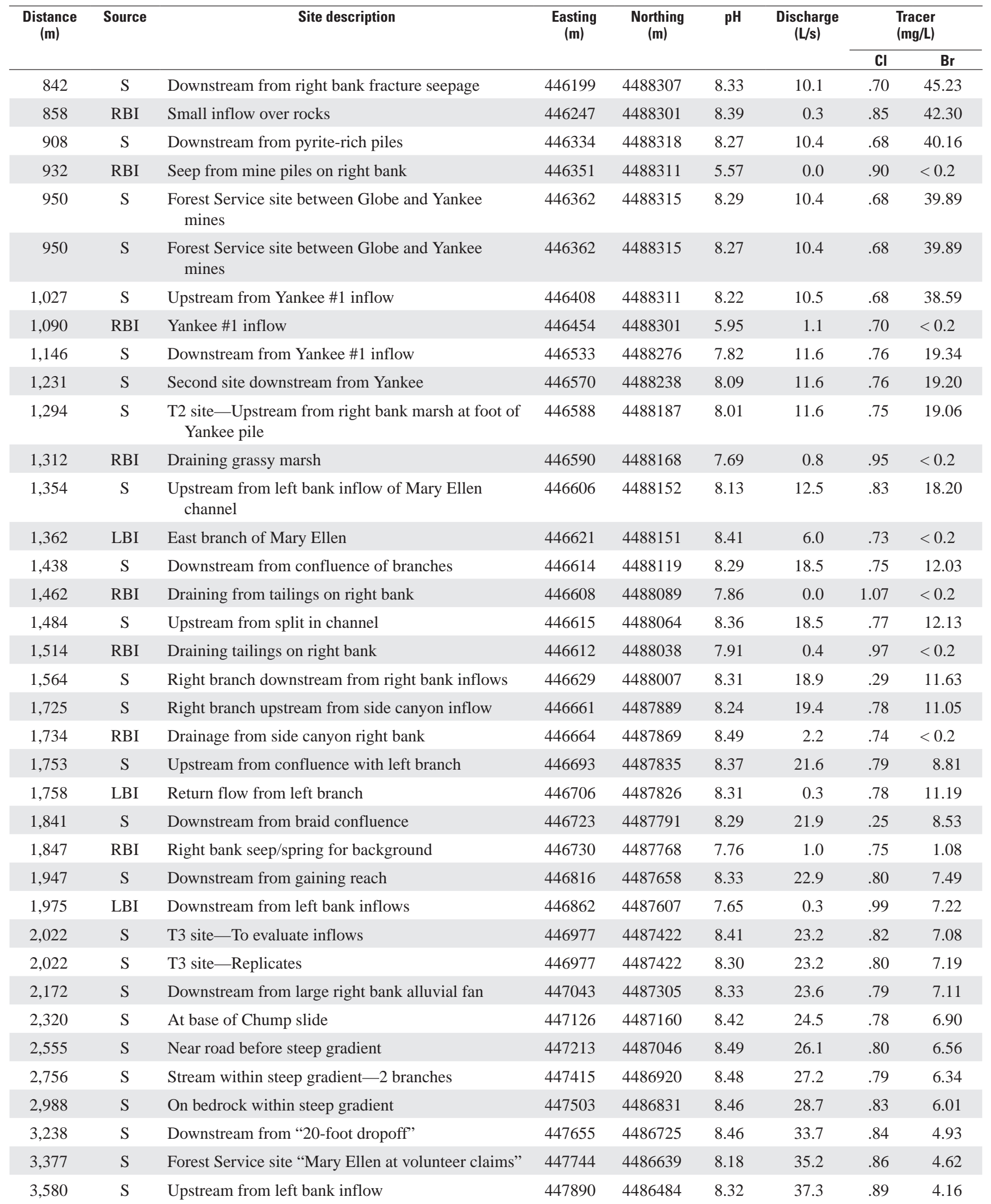


Table 1. Source, site description, $\mathrm{pH}$, calculated discharge, and tracer concentrations for synoptic samples from American Fork, October 1999, and Mary Ellen Gulch, Utah, September 2000.-Continued

\begin{tabular}{|c|c|c|c|c|c|c|c|c|}
\hline \multirow[t]{2}{*}{$\begin{array}{c}\text { Distance } \\
\text { (m) }\end{array}$} & \multirow[t]{2}{*}{ Source } & \multirow[t]{2}{*}{ Site description } & \multirow[t]{2}{*}{$\begin{array}{c}\text { Easting } \\
(\mathrm{m})\end{array}$} & \multirow[t]{2}{*}{$\begin{array}{c}\text { Northing } \\
\text { (m) }\end{array}$} & \multirow[t]{2}{*}{$\mathrm{pH}$} & \multirow[t]{2}{*}{$\begin{array}{c}\text { Discharge } \\
\text { (L/s) }\end{array}$} & \multicolumn{2}{|c|}{$\begin{array}{l}\text { Tracer } \\
\text { (mg/L) }\end{array}$} \\
\hline & & & & & & & $\mathbf{C I}$ & $\mathrm{Br}$ \\
\hline 3,592 & LBI & Left bank inflow of clean water & 447904 & 4486473 & 7.13 & 2.7 & 1.33 & $<0.2$ \\
\hline 3,724 & $\mathrm{~S}$ & Downstream from clean left bank inflow & 447996 & 4486359 & 8.35 & 40.1 & .89 & 3.58 \\
\hline 3,974 & $\mathrm{~S}$ & Within more chutes and pools & 448181 & 4486291 & 8.38 & 42.5 & .92 & 3.05 \\
\hline 4,603 & LBI & Upper American Fork & 448412 & 4486038 & 8.38 & 104 & 1.04 & $<0.2$ \\
\hline 4,713 & $\mathrm{~S}$ & First site within narrows & 448308 & 4485951 & 8.47 & 148 & 1.01 & .55 \\
\hline 4,765 & $\mathrm{~S}$ & Site to check ground-water inflow & 448174 & 4485883 & 8.42 & 151 & 1.04 & .54 \\
\hline 4,863 & $\mathrm{~S}$ & Second site to check ground-water inflow & 448038 & 4485800 & 8.50 & 154 & 1.09 & .53 \\
\hline
\end{tabular}

Specific conductance and $\mathrm{pH}$ were determined from the RU sample shortly after it was collected. In-line $0.45-\mu \mathrm{m}$ capsule filters were used to obtain the FU and FA samples. Metal concentrations in the RA, FA, and UFA samples were determined by using inductively coupled plasma-atomic emission spectrometry-mass spectrometry (Lichte and others, 1987). Anion concentrations in the FU samples were determined using ion chromatography (Brinton and others, 1996; Kimball and others, 1999). Total alkalinity in the FU sample was determined by using titration (Barringer and Johnsson, 1989).

Ultra-filtered and unfiltered treatments provided two operationally-defined concentrations of each metal. Metal concentration in the unfiltered sample (RA) was a measure of the total-recoverable concentration (dissolved + colloidal). In streams affected by mine drainage, this total-recoverable concentration accounted for $\mathrm{Al}$ and $\mathrm{Fe}$ colloids that will dissolve in the bottle after acidification. The ultra-filtered concentration (UFA) is an operational measure of the dissolved metal concentration. Colloidal metal concentrations are defined here as the difference between the total-recoverable (RA) and the ultra-filtered metal concentrations (UFA) in stream samples (Kimball and others, 1995). Aquatic standards for toxicity in Utah are based on $0.45-\mu \mathrm{m}$ filtration.

\section{Constituent Loads}

Mass load was calculated for each stream sampling site along the study reach as:

where:

$$
M_{\mathrm{A}}=C_{\mathrm{A}} Q_{\mathrm{A}}(0.0864)
$$

$M_{\mathrm{A}}$ is the constituent load, or mass flux, at location $\mathrm{A}$, in $\mathrm{kg} / \mathrm{day}$,

$C_{\mathrm{A}}$ is the concentration of the selected constituent at location $\mathrm{A}$, in $\mathrm{mg} / \mathrm{L}$,

$Q_{\mathrm{A}}$ is the discharge at location $\mathrm{A}$, in $\mathrm{L} / \mathrm{s}$, and

0.0864 is the conversion factor for changing $\mathrm{mg} / \mathrm{s}$ to $\mathrm{kg} /$ day.

The total sampled instream load was calculated from the total-recoverable concentration of the constituent, but the dissolved and the colloidal loads were calculated individually from the filtered and the total-recoverable concentrations. The longitudinal profiles of the sampled instream loads (total or dissolved plus colloidal) were derived from the basic data from the mass-loading study.

For each stream segment, the change in load between a pair of stream sites accounts for the gain or loss of constituent load for that segment. The change in load for the segment starting at site $\mathrm{A}$ and ending at site $\mathrm{B}$ is:

$$
\Delta M_{\mathrm{S}}=\left(M_{\mathrm{B}}-M_{\mathrm{A}}\right)
$$

where:

$$
\begin{aligned}
& M_{S} \text { is the change in sampled in-stream load from } \\
& \text { site A to B, in kg/day, } \\
& M_{B} \text { is the constituent load at site B, in kg/day, and } \\
& M_{A} \text { is defined in equation } 1 \text {. }
\end{aligned}
$$

Gains in constituent load ( $\Delta \mathrm{M}_{\mathrm{S}}$ is greater than zero) imply that a source exists and that it contributes load to the stream between the two stream sites. However, instream processes that reduce the net gain may also exist; thus, the measured change may not indicate the total magnitude of the source. Instream load also can decrease within a stream segment $\left(\Delta \mathrm{M}_{\mathrm{S}}\right.$ is less than zero), meaning that there is a net loss of the constituent as a result of physical, chemical, or biological processes. A net loss does not preclude the presence of a 
source of loading in a particular stream segment, but it does preclude quantifying the magnitude of that source. Summing all the increases in load between sampling sites along the study reach (positive values of $\Delta \mathrm{M}_{\mathrm{s}}$ ) leads to the cumulative instream load. At the end of the study reach, the cumulative instream load is the best estimate of the total load added to the stream but is likely a minimum estimate because it measures only the net loading between sites and does not account for metal loads added to and then lost from the water column within individual stream segments.

For those segments that include one or more sampled inflows, it is possible to evaluate how well the sampled inflow accounts for the instream changes. If stream sites A and B bracket one inflow sample from site I,

$$
\Delta M_{\mathrm{I}}=C_{\mathrm{I}}\left(Q_{\mathrm{B}}-Q_{\mathrm{A}}\right)(0.0864)
$$

where:

$$
\begin{aligned}
& M_{\mathrm{I}} \text { is the sampled inflow load from site A to B, in } \\
& \mathrm{kg} / \text { day, } \\
& C_{\mathrm{I}} \text { is the concentration of the selected constituent } \\
& \text { in inflow I, in } \mathrm{mg} / \mathrm{L} \text {, } \\
& Q_{\mathrm{B}} \text { is the discharge at site } \mathrm{B} \text {, in } \mathrm{L} / \mathrm{s} \text {, and } \\
& Q_{\mathrm{A}} \text { and } 0.0864 \text { are defined in equation } 1 .
\end{aligned}
$$

Equation 3 assumes that the entire increase in flow from site A to B was contributed by the sampled inflow and that $\mathrm{C}_{\mathrm{I}}$ represents the concentration of the solute in all the water entering the stream from site A to B. Summing the calculated inflow loads along the study reach produced a longitudinal profile of the cumulative inflow load that can be compared with the cumulative instream load. Commonly in streams affected by mine drainage, the cumulative instream load is greater than the cumulative inflow load. This result can indicate important areas where the load is not sampled (unsampled inflow), defined as:

where:

$$
\Delta M_{\mathrm{U}}=\left(M_{\mathrm{S}}-M_{\mathrm{I}}\right)
$$

$M_{U}$ is the unsampled load from site A to $B$, in $\mathrm{kg} / \mathrm{day}$, and

$M_{\mathrm{S}}$ and $M_{\mathrm{I}}$ are defined in equations 2 and 3.

If $\Delta \mathrm{M}_{\mathrm{I}}$ is greater than $\Delta \mathrm{M}_{\mathrm{S}}$ for a given stream segment, two explanations are possible, but they cannot be determined from the experimental data alone. First, the solute may be lost from the water column through chemical or biological processes, resulting in a smaller net value of $\Delta \mathrm{M}_{\mathrm{S}}$. Second, the sampled inflow concentration may not represent all the water entering the stream segment. Despite these limitations, quantifying $\Delta \mathrm{M}_{\mathrm{S}}, \Delta \mathrm{M}_{\mathrm{I}}$, and $\Delta \mathrm{M}_{\mathrm{U}}$ provides useful information for understanding the dynamics of solute loading to the stream (Bencala and Ortiz, 1999). Unsampled inflow can be calculated for individual stream segments or for the entire study reach. A negative value for the entire study reach does not preclude positive values for some individual stream segments.
Because measurement error is inherent in discharge estimates and chemical analysis, a load error equation was used to constrain the changes of sampled in-stream load. The load error is calculated from an equation that accounts for these potential sources of error (McKinnon, 2002).

where:

$$
\text { Load error }=\left(\sqrt{Q_{\mathrm{A}}^{2} \Delta C_{\mathrm{A}}^{2}+C_{\mathrm{A}}^{2} \Delta Q_{\mathrm{A}}^{2}}\right)(0.0864)
$$

$\Delta \mathrm{C}_{\mathrm{A}} \quad$ is the precision of chemical analysis, in percent,

$\Delta \mathrm{Q}_{\mathrm{A}} \quad$ is the precision of discharge calculation, and $Q_{\mathrm{A}}, C_{\mathrm{A}}$, and 0.0864 are defined in equation 1 .

The value of $\Delta \mathrm{C}_{\mathrm{A}}$ was calculated in a manner analogous to that used by Friedman and Erdman (1982) for single operator precision. The coefficient of variation (CV), representing precision, and the mean concentration were calculated for repeated analyses of a constituent in a set of standard reference samples that span a range of concentrations. Values for the CV were regressed as a power function of the mean concentrations to obtain an equation expressing analytical precision, $\Delta \mathrm{C}_{\mathrm{A}}$, as a function of concentration.

$$
\Delta C_{\mathrm{A}}=a\left(C_{\mathrm{A}}\right)^{b}
$$

where:

$$
\begin{gathered}
\Delta C_{\mathrm{A}} \text { is precision for the chemical analysis at site } \mathrm{A}, \\
\text { in percent, } \\
a \text { is the coefficient derived from regression, } \\
C_{\mathrm{A}} \text { is the concentration of the constituent at site } \\
\mathrm{A} \text {, and } \\
b, \quad \text { is the exponent derived from regression. }
\end{gathered}
$$

The value of $\Delta Q_{A}$ is based on the $C V$ for the plateau tracer concentration at the transport sites during the period of synoptic sampling. Similar to the procedure for analytical precision, the values of $\mathrm{CV}$ for each mean are used to develop a linear regression for $\Delta \mathrm{Q}_{\mathrm{A}}$ :

where:

$$
\Delta Q_{\mathrm{A}}=m C_{\mathrm{A}}^{\mathrm{T}}+b
$$

$\Delta Q_{\mathrm{A}}$ is the discharge error at site $\mathrm{A}$,

$m$ is the slope derived from the linear regression,

$C_{\mathrm{A}}^{\mathrm{T}}$ is the tracer concentration at site $\mathrm{A}$, and

$b$, is the intercept derived from the linear regression.

Both $\Delta \mathrm{C}_{\mathrm{A}}$ and $\Delta \mathrm{Q}_{\mathrm{A}}$ give the percentage of $\mathrm{C}_{\mathrm{A}}$ and $\mathrm{Q}_{\mathrm{A}}$ to be substituted into equation 6 to calculate load error. The load error was compared to the change in load to the next site, $\Delta \mathrm{M}_{\mathrm{B}-\mathrm{A}}$. If the absolute value of $\Delta \mathrm{M}_{\mathrm{B}-\mathrm{A}}$ was greater than the load error, then a measurable and significant change in load occurred. This error check was applied to values of $\Delta \mathrm{M}_{\mathrm{B}-\mathrm{A}}$ that were used for the cumulative in-stream load only; sampled instream load is reported for all observed changes. 


\section{Results of Mass-Loading Studies}

\section{Chemical Analysis of Synoptic Samples}

Results of chemical analyses of synoptic samples are presented in tables 2 and 3 . Both stream and inflow samples are included and are listed in downstream order for the separate synoptic sampling days. These tables contain three rows of data for stream samples, including the analyses for the UFA, FA, and RA treatments. Most inflow samples have two rows, one to report results from the FA sample and another for results from the RA sample. Occasionally, concentrations from the UFA sample or the FA sample were greater than the concentrations from the RA sample for a given constituent, but the two concentrations usually were within analytical precision.

Analytical results indicate that some of the $\mathrm{Cu}$ and $\mathrm{Zn}$ concentrations from UFA and FA samples had been contaminated. The contamination was likely caused by the brass fittings contacting the tangential-filtration apparatus while the filters were being changed between the FA and UFA treatments. Samples considered to be contaminated are indicated in table 3. When the concentration from the RA sample was lower than the concentration from either the UFA or FA samples, the interpretation can become subjective. In this study, when this situation occurred because of contamination, we substituted the concentration from the RA sample for the filtered and the total-recoverable concentrations, and assigned a value to the colloidal concentration that was less than the detection limit. However, if upstream and downstream samples were not contaminated and substantial colloidal concentrations were present, we used the average of those colloidal percentages to calculate a colloidal concentration for the sample affected by contamination. This approach helped to avoid a zigzag pattern of colloidal concentrations.

Quality assurance results are given in table 4 . These include the method detection limits (MDL) for each constituent and parameters derived from the application of equation 7, using the value of the relative standard deviation (RSD) and the mean concentration for various standard reference samples. The RSD and mean values were obtained by running standard reference samples after every group of 10 samples were analyzed. The RSD was used as the measure of precision for the chemical analyses.

\section{Loading Profiles}

Using the equations described in "Constituent Loads," the mass-loading profiles for $\mathrm{Al}, \mathrm{Fe}, \mathrm{Mn}$, and $\mathrm{Zn}$ are illustrated for American Fork (figs. 2-5) and Mary Ellen Gulch (figs. 6, 7, 9, and 10). The profile for $\mathrm{Cu}$ is shown for Mary Ellen Gulch only (fig. 8). Each figure indicates the longitudinal profile of load and the change in load for individual stream segments.

\section{References Cited}

Barringer, J.L., and Johnsson, P.A., 1989, Theoretical considerations and a simple method for measuring alkalinity and acidity in low pH waters by Gran titration: U.S. Geological Survey Water-Resources Investigations Report 89-4029, $35 \mathrm{p}$.

Bencala, K.E., and McKnight, D.M., 1987, Identifying instream variability: Sampling iron in an acidic stream, in Averett, R.C., and McKnight, D.M., eds., Chemical quality of water and the hydrologic cycle, Chelsea, Michigan, Lewis Publishers, Inc., p. 255-269.

Bencala, K.E., McKnight, D.M., and Zellweger, G.W., 1990, Characterization of transport in an acidic and metal-rich mountain stream based on a lithium tracer injection and simulations of transient storage: Water Resources Research, v. 26, p. 989-1000.

Bencala, K.E., and Ortiz, R.F., 1999, Theory and(or) reality: Analysis of sulfate mass-balance at Summitville, Colorado, poses process questions about the estimation of metal loadings, in U.S. Geological Survey Toxic Substances Hydrology Program-Proceedings of the Technical Meeting, Charleston, South Carolina, March 8-12, 1999-Volume 1 of 3-Contamination from Hardrock Mining: U.S. Geological Survey Water-Resources Investigations Report 99-4018A, p. 119-122.

Brinton, T.I., Antweiler, R.C., and Taylor, H.E., 1996, Method for the determination of dissolved chloride, nitrate, and sulfate in natural water using ion chromatography: U.S. Geological Survey Open-File Report 95-426A, 16 p.

Broshears, R.E., Bencala, K.E., Kimball, B.A., and McKnight, D.M., 1993, Tracer-dilution experiments and solute-transport simulations for a mountain stream, Saint Kevin Gulch, Colorado: U.S. Geological Survey Water-Resources Investigations Report 92-4081, 18 p.

Buxton, H.T., Nimick, D.A., von Guerard, P.B., Church, S.E., Frazier, A.G., Gray, J.R., Lipin, B.R., Marsh, S.P., Woodward, D.F., Kimball, B.A., Finger, S.E., Ischinger, L.S., Fordham, J.C., Power, M.S., Bunck, C.M., and Jones, J.W., 1997, A science-based, watershed strategy to support effective remediation of abondoned mine lands, in Fourth International Conference on Acid Rock Drainage: Vancouver, British Columbia, Canada, ICARD, p. 1869-1880.

Friedman, L.C., and Erdmann, D.E., 1982, Quality assurance practices for the chemical and biological analyses of water and fluvial sediments: U.S. Geological Survey Techniques of Water-Resources Investigations, book 5, chap. A6, $181 \mathrm{p}$.

Jarrett, R.D., 1992, Hydraulics of mountain rivers, in Channel flow resistance centennial of Manning's and Kuichling's rational formula: Littleton, Colorado, Water Resources Publications, p. 287-298. 
Kilpatrick, F.A., and Cobb, E.D., 1985, Measurement of discharge using tracers: U.S. Geological Survey Techniques of Water-Resources Investigations book 3, chap. A16, 27 p.

Kimball, B.A., Broshears, R.E., Bencala, K.E., and McKnight, D.M., 1994, Coupling of hydrologic transport and chemical reactions in a stream affected by acid mine drainage: Environmental Science \& Technology, v. 28, p. 2065-2073.

Kimball, B.A., Callender, E., and Axtmann, E.V., 1995, Effects of colloids on metal transport in a river receiving acid mine drainage, Upper Arkansas River, Colorado, USA: Applied Geochemistry, v. 10, p. 285-306.

Kimball, B.A., Nimick, D.A., Gerner, L.J., and Runkel, R.L., 1999, Quantification of metal loading in Fisher Creek by tracer injection and synoptic sampling, Park County, Montana, August 1997: U.S. Geological Survey WaterResources Investigations Report 99-4119, 40 p.

Kimball, B.A., Nordstrom, D.K., Runkel, R.L., Vincent, K.R., and Verplanck, P.L., 2006a, Questa baseline and pre-mining ground-water quality investigation. 23. Quantification of mass loading from mined and unmined areas along the Red River, New Mexico: U.S. Geological Survey Scientific Investigations Report 2006-5004, 44 p.

Kimball, B.A., Runkel, R.L., Walton-Day, K., and Bencala, K.E., 2002, Assessment of metal loads in watersheds affected by acid mine drainage by using tracer injection and synoptic sampling: Cement Creek, Colorado, USA: Applied Geochemistry, v. 17, no. 9, p. 1183-1207.

Kimball, B.A., Runkel, R.L., Walton-Day, K., and Williamson, J.E., 2006b, Quantification of mass loading to Strawberry Creek near the Gilt Edge mine, South Dakota: U.S. Geological Survey Scientific Investigations Report 2006-5006, $41 \mathrm{p}$.

Lichte, F.E., Golightly, D.W., and Lamothe, P.J., 1987, Inductively coupled plasma-atomic emission spectrometry: U.S. Geological Survey Bulletin 1770, p. B10.

McKinnon, T.E., 2002, Sources and seasonal variability of metal and arsenic concentrations in the surface water of the Clark Fork River Basin, Montana: University of Montana, Master of Science thesis, $115 \mathrm{p}$.

Rantz, S.E., 1982, Measurement and computation of streamflow: Volume 1. Measurement of stage and discharge: U.S. Geological Survey Water-Supply Paper 2175, 200 p.

Ward, J.R., and Harr, C.A., 1990, Methods for collection and processing of surface-water and bed-material samples for physical and chemical analyses: U.S. Geological Survey Open-File Report 90-140, 71 p.
Zellweger, G.W., Avanzino, R.J., and Bencala, K.E., 1989, Comparison of tracer-dilution and current-meter discharge measurements in a small gravel-bed stream, Little Lost Man Creek, California: Water-Resources Investigations Report 89-4150, 20 p. 
Table 2. Chemical analyses for major ions in water samples from American Fork, October 1999, and Mary Ellen Gulch, Utah, September 2000.

[Distance, from injection, in meters (m). Source: S, stream; RBI, right-bank inflow; LBI, left-bank inflow. Filter: UFA, 10,000 Dalton ultra-filter; FA, 0.45-micrometer filter; RA, unfiltered; $\mathrm{CaCO}_{3}$, calcium carbonate; <, less than; NM, not measured; all concentrations in milligrams per liter]

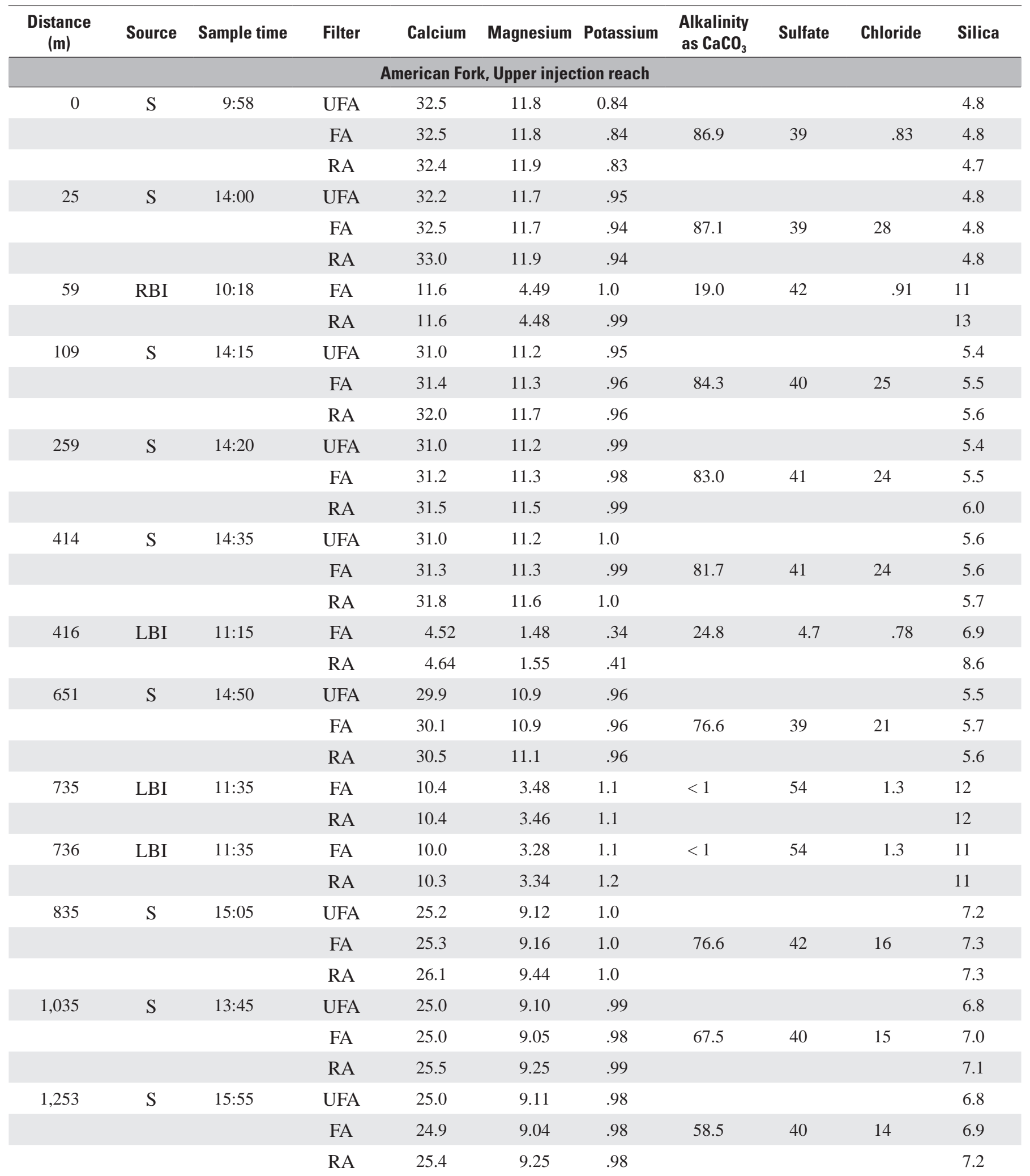


Table 2. Chemical analyses for major ions in water samples from American Fork, October 1999, and Mary Ellen Gulch, Utah, September 2000.-Continued

\begin{tabular}{|c|c|c|c|c|c|c|c|c|c|c|}
\hline $\begin{array}{c}\text { Distance } \\
\text { (m) }\end{array}$ & Source & Sample time & Filter & Calcium & Magnesium & Potassium & $\begin{array}{l}\text { Alkalinity } \\
\text { as } \mathrm{CaCO}_{3}\end{array}$ & Sulfate & Chloride & Silica \\
\hline \multirow[t]{3}{*}{1,603} & $S$ & $16: 20$ & UFA & 24.9 & 9.28 & .95 & & & & 6.7 \\
\hline & & & FA & 25.2 & 9.33 & .98 & 63.0 & 38 & 12 & 6.9 \\
\hline & & & RA & 25.8 & 9.59 & .99 & & & & 7.2 \\
\hline \multirow[t]{3}{*}{2,003} & S & $16: 35$ & UFA & 28.2 & 11.1 & .89 & & & & 6.8 \\
\hline & & & FA & 28.1 & 11.0 & .88 & 80.2 & 32 & 7.2 & 6.7 \\
\hline & & & RA & 28.3 & 11.1 & .87 & & & & 6.6 \\
\hline \multicolumn{11}{|c|}{ American Fork, Lower injection reach } \\
\hline \multirow[t]{3}{*}{2,983} & $S$ & $15: 10$ & UFA & 34.0 & 14.6 & .71 & & & & 5.7 \\
\hline & & & FA & 34.8 & 15.0 & .70 & 119 & 23 & 1.2 & 6.6 \\
\hline & & & RA & 35.5 & 15.3 & .71 & & & & 6.8 \\
\hline \multirow[t]{3}{*}{3,123} & S & $15: 05$ & UFA & 33.8 & 14.6 & .71 & & & & 6.0 \\
\hline & & & FA & 34.7 & 15.0 & .70 & 119 & 24 & 1.2 & 6.5 \\
\hline & & & RA & 34.8 & 15.0 & .74 & & & & 6.5 \\
\hline \multirow[t]{2}{*}{3,128} & LBI & $15: 00$ & FA & 29.9 & 15.4 & .37 & & 3.4 & 1.2 & 5.7 \\
\hline & & & RA & 30.4 & 15.7 & .34 & 128 & & & 5.3 \\
\hline \multirow[t]{2}{*}{3,198} & LBI & $14: 55$ & FA & 30.0 & 15.5 & .39 & 128 & 3.2 & 1.2 & 5.7 \\
\hline & & & RA & 30.2 & 15.6 & .40 & & & & 5.4 \\
\hline \multirow[t]{2}{*}{3,303} & LBI & $14: 50$ & FA & 30.9 & 15.8 & .41 & 132 & 3.1 & 1.3 & 5.8 \\
\hline & & & RA & 31.7 & 16.3 & .41 & & & & 6.0 \\
\hline \multirow[t]{2}{*}{3,331} & LBI & $14: 45$ & FA & 36.1 & 18.2 & .48 & 155 & 3.2 & 1.4 & 6.3 \\
\hline & & & RA & 36.2 & 18.2 & .50 & 155 & & & 5.9 \\
\hline \multirow[t]{3}{*}{3,344} & $S$ & $14: 33$ & UFA & 32.7 & 15.1 & .59 & 119 & & & 5.6 \\
\hline & & & FA & 33.3 & 15.4 & .57 & 119 & 15 & 1.2 & 6.3 \\
\hline & & & RA & 33.9 & 15.7 & .56 & 119 & & & 6.4 \\
\hline \multirow[t]{2}{*}{3,345} & RBI & $14: 35$ & FA & 45.2 & 23.1 & .72 & 173 & 25 & 1.5 & 7.6 \\
\hline & & & RA & 46.1 & 23.5 & .72 & 173 & & & 7.5 \\
\hline \multirow[t]{2}{*}{3,385} & LBI & $14: 30$ & FA & 38.8 & 19.5 & .47 & 165 & 3.7 & 1.6 & 7.6 \\
\hline & & & RA & 39.7 & 19.7 & .53 & 165 & & & 6.6 \\
\hline \multirow[t]{3}{*}{3,470} & $S$ & $14: 20$ & UFA & 33.2 & 15.4 & .59 & 127 & & & 5.6 \\
\hline & & & FA & 33.6 & 15.7 & .57 & 127 & 14 & 1.3 & 7.4 \\
\hline & & & RA & 34.0 & 15.9 & .54 & 127 & & & 6.4 \\
\hline \multirow[t]{3}{*}{3,475} & RBI & $14: 15$ & UFA & 44.6 & 23.0 & .84 & 172 & & & 6.4 \\
\hline & & & FA & 45.7 & 23.5 & .81 & 172 & 36 & 1.6 & 6.8 \\
\hline & & & RA & 46.8 & 24.2 & .86 & 172 & & & 8.1 \\
\hline \multirow[t]{2}{*}{3,485} & RBI & $14: 10$ & FA & 43.3 & 22.8 & .80 & 158 & NM & NM & 7.6 \\
\hline & & & RA & 43.9 & 23.2 & .83 & 158 & & & 7.7 \\
\hline \multirow[t]{3}{*}{3,625} & S & $13: 55$ & UFA & 33.3 & 15.6 & .61 & 128 & & & 5.8 \\
\hline & & & FA & 34.0 & 15.9 & .58 & 128 & 14 & 1.2 & 6.3 \\
\hline & & & RA & 34.5 & 16.2 & .56 & 128 & & & 6.3 \\
\hline
\end{tabular}


Table 2. Chemical analyses for major ions in water samples from American Fork, October 1999, and Mary Ellen Gulch, Utah, September 2000.-Continued

\begin{tabular}{|c|c|c|c|c|c|c|c|c|c|c|}
\hline $\begin{array}{c}\text { Distance } \\
(\mathrm{m})\end{array}$ & Source & Sample time & Filter & Calcium & Magnesium & Potassium & $\begin{array}{l}\text { Alkalinity } \\
\text { as } \mathrm{CaCO}_{3}\end{array}$ & Sulfate & Chloride & Silica \\
\hline \multirow[t]{3}{*}{3,625} & S & $14: 00$ & UFA & 33.3 & 15.6 & .59 & 128 & & & 5.6 \\
\hline & & & FA & 34.3 & 16.0 & .57 & 128 & 15 & 1.4 & 6.3 \\
\hline & & & RA & 34.6 & 16.3 & .56 & 128 & & & 6.3 \\
\hline \multirow[t]{3}{*}{3,775} & S & 13:56 & UFA & 33.4 & 15.6 & .60 & 128 & & & 5.5 \\
\hline & & & FA & 34.2 & 16.0 & .59 & 128 & 15 & 1.3 & 7.7 \\
\hline & & & RA & 34.3 & 16.1 & .61 & 128 & & & 6.0 \\
\hline \multirow[t]{3}{*}{4,035} & $S$ & $13: 40$ & UFA & 33.3 & 15.6 & .61 & 128 & & & 5.5 \\
\hline & & & FA & 33.9 & 15.9 & .58 & 128 & 15 & 1.3 & 7.6 \\
\hline & & & RA & 34.1 & 16.1 & .60 & 128 & & & 5.9 \\
\hline \multirow[t]{2}{*}{4,200} & RBI & $13: 25$ & FA & 45.5 & 23.7 & .50 & 168 & 4.3 & 1.6 & 8.0 \\
\hline & & & RA & 45.8 & 23.7 & .55 & 168 & & & 7.7 \\
\hline \multirow[t]{2}{*}{4,255} & RBI & $13: 20$ & FA & 29.6 & 18.8 & 1.7 & 139 & 7.7 & 1.5 & 6.3 \\
\hline & & & $\mathrm{RA}$ & 48.7 & 19.8 & 2.0 & 139 & & & 8.0 \\
\hline \multirow[t]{3}{*}{4,385} & S & $13: 10$ & UFA & 33.9 & 16.0 & .60 & 128 & & & 5.9 \\
\hline & & & FA & 34.7 & 16.3 & .56 & 128 & 15 & 1.3 & 6.4 \\
\hline & & & $\mathrm{RA}$ & 34.6 & 16.3 & .60 & 128 & & & 5.9 \\
\hline \multirow[t]{2}{*}{4,435} & LBI & 13:05 & FA & 43.4 & 20.1 & .61 & 152 & 12 & 1.3 & 6.8 \\
\hline & & & RA & 43.7 & 20.2 & .64 & 152 & & & 6.3 \\
\hline 4,515 & RBI & 13:00 & RA & 37.5 & 17.5 & .63 & 145 & 14 & 1.4 & 6.0 \\
\hline \multirow[t]{3}{*}{4,665} & $S$ & $12: 50$ & UFA & 36.3 & 17.0 & .60 & 141 & & & 5.8 \\
\hline & & & FA & 37.0 & 17.5 & .58 & 141 & 13 & 1.3 & 6.6 \\
\hline & & & $\mathrm{RA}$ & 37.8 & 17.8 & .62 & 141 & & & 6.1 \\
\hline \multirow[t]{3}{*}{4,965} & $S$ & $12: 35$ & UFA & 36.3 & 17.3 & .60 & 143 & & & 5.0 \\
\hline & & & FA & 37.5 & 17.6 & .58 & 143 & 14 & 1.3 & 6.4 \\
\hline & & & RA & 37.2 & 17.4 & .61 & 143 & & & 6.1 \\
\hline \multirow[t]{2}{*}{5,065} & RBI & $12: 10$ & FA & 53.7 & 23.5 & .58 & 153 & 4.9 & 1.6 & 7.8 \\
\hline & & & $\mathrm{RA}$ & 53.8 & 23.5 & .61 & 153 & & & 7.5 \\
\hline \multirow[t]{3}{*}{5,138} & $S$ & 12:00 & UFA & 36.8 & 17.3 & .61 & 142 & & & 6.0 \\
\hline & & & FA & 37.6 & 17.6 & .58 & 142 & 14 & 1.4 & 6.3 \\
\hline & & & RA & 37.7 & 17.6 & .60 & 142 & & & 6.1 \\
\hline \multirow[t]{2}{*}{5,140} & RBI & $11: 55$ & FA & 57.2 & 25.0 & .55 & 142 & 2.9 & 1.6 & 8.2 \\
\hline & & & RA & 57.4 & 24.9 & .57 & 142 & & & 7.7 \\
\hline \multirow[t]{3}{*}{5,370} & $S$ & $11: 35$ & UFA & 36.0 & 17.0 & .59 & 144 & & & 4.9 \\
\hline & & & FA & 37.8 & 17.7 & .58 & 144 & 14 & 1.3 & 6.3 \\
\hline & & & $\mathrm{RA}$ & 37.8 & 17.6 & .60 & 144 & & & 5.9 \\
\hline \multirow[t]{3}{*}{5,715} & $S$ & $11: 25$ & UFA & 37.4 & 17.4 & .61 & 147 & & & 5.7 \\
\hline & & & FA & 38.1 & 17.8 & .58 & 147 & 14 & 1.3 & 6.4 \\
\hline & & & $\mathrm{RA}$ & 37.9 & 17.7 & .60 & 147 & & & 5.9 \\
\hline
\end{tabular}


Table 2. Chemical analyses for major ions in water samples from American Fork, October 1999, and Mary Ellen Gulch, Utah, September 2000.-Continued

\begin{tabular}{|c|c|c|c|c|c|c|c|c|c|c|}
\hline $\begin{array}{c}\text { Distance } \\
(\mathrm{m})\end{array}$ & Source & Sample time & Filter & Calcium & Magnesium & Potassium & $\begin{array}{l}\text { Alkalinity } \\
\text { as } \mathrm{CaCO}_{3}\end{array}$ & Sulfate & Chloride & Silica \\
\hline \multirow[t]{3}{*}{6,065} & S & 11:05 & UFA & 36.7 & 17.7 & .60 & 149 & & & 5.2 \\
\hline & & & FA & 38.3 & 17.9 & .59 & 149 & 14 & 1.4 & 6.3 \\
\hline & & & RA & 38.4 & 17.9 & .60 & 149 & & & 6.1 \\
\hline \multirow[t]{3}{*}{6,275} & S & 10:55 & UFA & 37.0 & 17.3 & .60 & 150 & & & 5.1 \\
\hline & & & FA & 37.9 & 17.7 & .59 & 150 & 13 & 1.4 & 6.2 \\
\hline & & & RA & 38.2 & 17.8 & .61 & 150 & & & 6.1 \\
\hline \multirow[t]{3}{*}{6,275} & S & $17: 15$ & UFA & 36.8 & 17.7 & .64 & 150 & & & 5.2 \\
\hline & & & FA & 38.0 & 17.8 & .62 & 150 & 13 & 1.4 & 6.3 \\
\hline & & & RA & 38.0 & 17.6 & .65 & 150 & & & 6.0 \\
\hline \multirow[t]{2}{*}{6,290} & RBI & 10:50 & FA & 35.2 & 13.3 & .55 & 104 & 30 & 1.0 & 6.4 \\
\hline & & & RA & 35.2 & 13.3 & .57 & 104 & & & 6.0 \\
\hline \multirow[t]{3}{*}{6,452} & S & 10:40 & UFA & 37.0 & 16.8 & .61 & 141 & & & 5.9 \\
\hline & & & FA & 37.4 & 17.0 & .57 & 141 & 16 & 1.3 & 6.1 \\
\hline & & & RA & 37.8 & 17.1 & .61 & 141 & & & 6.2 \\
\hline \multirow[t]{3}{*}{6,717} & S & 10:25 & UFA & 36.2 & 16.6 & .85 & 141 & & & 5.1 \\
\hline & & & FA & 37.7 & 17.0 & .58 & 141 & 16 & 1.3 & 6.3 \\
\hline & & & RA & 38.4 & 17.4 & .65 & 141 & & & 6.8 \\
\hline \multirow[t]{3}{*}{8,387} & S & $16: 25$ & UFA & 37.3 & 17.1 & .36 & 143 & & & 5.1 \\
\hline & & & FA & 38.5 & 17.2 & .61 & 143 & 16 & 1.3 & 6.5 \\
\hline & & & RA & 38.9 & 17.4 & .60 & 143 & & & 6.5 \\
\hline \multirow[t]{3}{*}{8,407} & RBI & 16:00 & UFA & 45.0 & 18.6 & .58 & 137 & & & 5.5 \\
\hline & & & FA & 45.7 & 19.0 & .54 & 137 & 11 & 1.1 & 6.1 \\
\hline & & & RA & 45.3 & 18.8 & .57 & 137 & & & 5.6 \\
\hline \multirow[t]{3}{*}{8,507} & S & $15: 45$ & UFA & 37.9 & 16.8 & .63 & 143 & & & 6.0 \\
\hline & & & FA & 39.0 & 17.4 & .61 & 143 & 16 & 1.3 & 7.6 \\
\hline & & & RA & 38.9 & 17.5 & .59 & 143 & & & 6.5 \\
\hline \multirow[t]{3}{*}{10,287} & $S$ & 13:05 & UFA & 45.2 & 17.9 & .61 & 118 & & & 6.2 \\
\hline & & & FA & 47.1 & 18.7 & .59 & 118 & 23 & 1.5 & 8.6 \\
\hline & & & RA & 46.3 & 18.5 & .55 & 118 & & & 6.6 \\
\hline \multirow[t]{3}{*}{10,307} & RBI & 12:45 & UFA & 64.1 & 7.59 & .62 & 81.4 & & & 8.8 \\
\hline & & & FA & 65.1 & 7.79 & .60 & 81.4 & 41 & 2.3 & 12 \\
\hline & & & $\mathrm{RA}$ & 65.4 & 7.83 & .63 & 81.4 & & & 9.5 \\
\hline \multirow[t]{3}{*}{10,407} & S & $12: 20$ & UFA & 45.3 & 17.7 & .60 & 159 & & & 6.2 \\
\hline & & & FA & 45.5 & 17.7 & .56 & 159 & 23 & 1.7 & 6.9 \\
\hline & & & RA & 46.0 & 18.2 & .54 & 159 & & & 7.0 \\
\hline \multirow[t]{3}{*}{11,962} & S & 11:10 & UFA & 83.1 & 26.2 & .71 & NM & & & 10 \\
\hline & & & FA & 84.4 & 26.6 & .67 & NM & 140 & 2.1 & 11 \\
\hline & & & RA & 84.7 & 26.7 & .66 & NM & & & 11 \\
\hline
\end{tabular}


Table 2. Chemical analyses for major ions in water samples from American Fork, October 1999, and Mary Ellen Gulch, Utah, September 2000.-Continued

\begin{tabular}{|c|c|c|c|c|c|c|c|c|c|c|}
\hline $\begin{array}{l}\text { Distance } \\
(\mathrm{m})\end{array}$ & Source & Sample time & Filter & Calcium & Magnesium & Potassium & $\begin{array}{l}\text { Alkalinity } \\
\text { as } \mathrm{CaCO}_{3}\end{array}$ & Sulfate & Chloride & Silica \\
\hline \multicolumn{11}{|c|}{ Mary Ellen Gulch } \\
\hline \multirow[t]{3}{*}{163} & $S$ & $16: 12$ & UFA & 6.40 & 2.00 & .67 & $<1$ & & & 9.5 \\
\hline & & & FA & 6.25 & 1.89 & .75 & $<1$ & 44 & .75 & 9.5 \\
\hline & & & RA & 7.00 & 1.89 & .63 & $<1$ & & & 9.9 \\
\hline \multirow[t]{3}{*}{172} & S & 16:10 & UFA & 6.40 & 1.82 & 1.5 & $<1$ & & & 9.1 \\
\hline & & & FA & 6.30 & 1.78 & 1.4 & $<1$ & 40 & .87 & 8.8 \\
\hline & & & RA & 6.20 & 1.73 & 1.5 & $<1$ & & & 8.5 \\
\hline \multirow[t]{2}{*}{178} & RBI & $16: 10$ & FA & 6.50 & 2.35 & .98 & $<1$ & 55 & .83 & 12 \\
\hline & & & RA & 6.90 & 2.42 & .77 & $<1$ & & & 11 \\
\hline \multirow[t]{3}{*}{270} & S & $16: 00$ & UFA & 6.70 & 1.95 & .69 & $<1$ & & & 10 \\
\hline & & & FA & 6.35 & 1.99 & 1.4 & $<1$ & 44 & .48 & 9.9 \\
\hline & & & $\mathrm{RA}$ & 6.95 & 2.05 & 1.4 & $<1$ & & & 8.9 \\
\hline \multirow[t]{3}{*}{370} & S & $15: 50$ & UFA & 7.60 & 1.99 & 1.4 & $<1$ & & & 11 \\
\hline & & & FA & 6.75 & 2.10 & 1.3 & $<1$ & 43 & .76 & 9.7 \\
\hline & & & $\mathrm{RA}$ & 7.45 & 2.08 & 1.3 & $<1$ & & & 9.9 \\
\hline \multirow[t]{2}{*}{397} & RBI & $15: 50$ & FA & 23.0 & 6.15 & .60 & 63.7 & 23 & .63 & 3.8 \\
\hline & & & $\mathrm{RA}$ & 25.0 & 6.70 & .74 & 63.7 & & & 4.2 \\
\hline \multirow[t]{3}{*}{447} & S & $15: 42$ & UFA & 7.85 & 2.38 & 1.4 & $<1$ & & & 10 \\
\hline & & & FA & 8.00 & 2.25 & 1.1 & $<1$ & 43 & .52 & 10 \\
\hline & & & $\mathrm{RA}$ & 7.90 & 2.30 & 1.4 & $<1$ & & & 10 \\
\hline \multirow[t]{2}{*}{488} & RBI & $15: 40$ & FA & 32.0 & 14.2 & .40 & 112 & 16 & .78 & 3.5 \\
\hline & & & RA & 32.5 & 14.5 & .40 & 112 & & & 3.6 \\
\hline \multirow[t]{3}{*}{540} & $S$ & $15: 33$ & UFA & 20.0 & 5.80 & .39 & 40.0 & & & 6.2 \\
\hline & & & FA & 19.0 & 6.00 & .80 & 40.0 & 30 & .63 & 5.9 \\
\hline & & & RA & 20.0 & 6.15 & .80 & 40.0 & & & 6.3 \\
\hline \multirow[t]{2}{*}{633} & RBI & $15: 30$ & UFA & 32.0 & 15.0 & .38 & 104 & & & 3.8 \\
\hline & & & FA & 31.0 & 14.7 & .32 & 104 & 18 & .73 & 3.6 \\
\hline 633 & RBI & $15: 30$ & $\mathrm{RA}$ & 33.0 & 16.0 & .37 & 104 & & & 3.6 \\
\hline \multirow[t]{2}{*}{685} & $S$ & $15: 23$ & FA & 23.0 & 8.71 & .70 & 60.0 & 27 & .70 & 5.2 \\
\hline & & & $\mathrm{RA}$ & 24.0 & 8.25 & .68 & 60.0 & & & 4.7 \\
\hline \multirow[t]{3}{*}{735} & $S$ & $15: 20$ & UFA & 21.5 & 8.40 & .62 & 62.7 & & & 5.1 \\
\hline & & & FA & 22.5 & 8.58 & .79 & 62.7 & 27 & .68 & 5.1 \\
\hline & & & RA & 22.0 & 8.97 & .61 & 62.7 & & & 4.9 \\
\hline \multirow[t]{3}{*}{758} & S & $15: 12$ & UFA & 24.0 & 9.35 & .45 & 65.1 & & & 5.1 \\
\hline & & & FA & 23.5 & 9.16 & .69 & 65.1 & 27 & .68 & 5.0 \\
\hline & & & RA & 22.5 & 9.26 & .68 & 65.1 & & & 4.8 \\
\hline \multirow[t]{2}{*}{760} & RBI & $15: 10$ & FA & 34.0 & 14.3 & .26 & 96.1 & 27 & .71 & 4.0 \\
\hline & & & $\mathrm{RA}$ & 27.0 & 15.1 & .18 & 96.1 & & & 3.6 \\
\hline
\end{tabular}


Table 2. Chemical analyses for major ions in water samples from American Fork, October 1999, and Mary Ellen Gulch, Utah, September 2000.-Continued

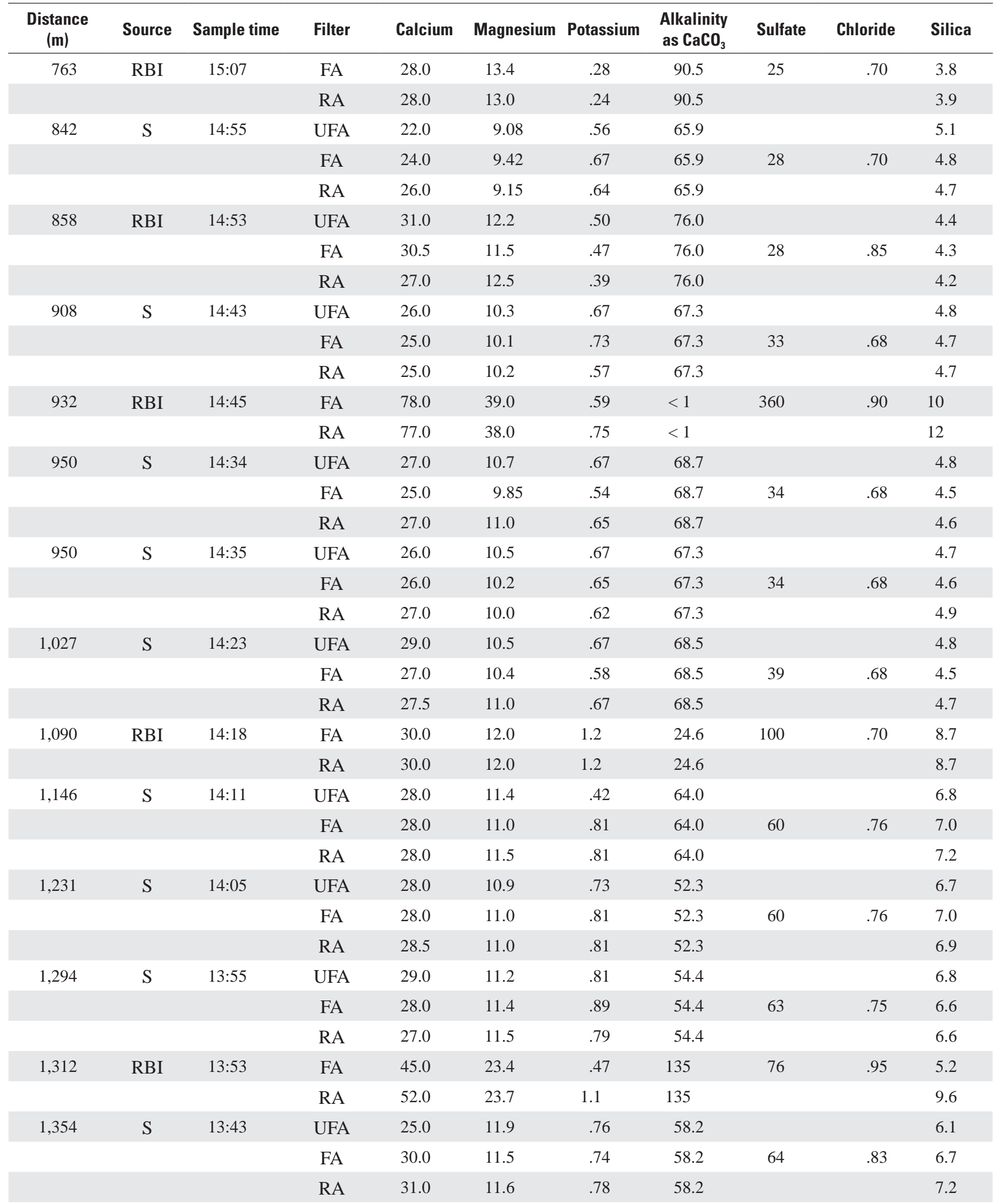


Table 2. Chemical analyses for major ions in water samples from American Fork, October 1999, and Mary Ellen Gulch, Utah, September 2000.-Continued

\begin{tabular}{|c|c|c|c|c|c|c|c|c|c|c|}
\hline $\begin{array}{c}\text { Distance } \\
(\mathrm{m})\end{array}$ & Source & Sample time & Filter & Calcium & Magnesium & Potassium & $\begin{array}{l}\text { Alkalinity } \\
\text { as } \mathrm{CaCO}_{3}\end{array}$ & Sulfate & Chloride & Silica \\
\hline \multirow[t]{3}{*}{1,362} & LBI & 13:42 & UFA & 31.0 & 11.2 & .39 & 42.3 & & & 3.6 \\
\hline & & & FA & 33.0 & 11.4 & .45 & 42.3 & 18 & .73 & 3.8 \\
\hline & & & RA & 36.0 & 10.7 & .50 & 42.3 & & & 4.0 \\
\hline \multirow[t]{3}{*}{1,438} & S & 13:34 & UFA & 30.0 & 12.1 & .67 & 72.6 & & & 5.6 \\
\hline & & & FA & 29.0 & 12.0 & .66 & 72.6 & 50 & .75 & 5.6 \\
\hline & & & RA & 27.0 & 12.5 & .54 & 72.6 & & & 5.3 \\
\hline \multirow[t]{3}{*}{1,462} & RBI & 13:32 & UFA & 52.0 & 24.6 & .47 & 154 & & & 6.1 \\
\hline & & & FA & 49.0 & 23.9 & .93 & 154 & 58 & 1.1 & 6.0 \\
\hline & & & RA & 56.0 & 24.7 & .87 & 154 & & & 6.3 \\
\hline \multirow[t]{3}{*}{1,484} & S & 13:15 & UFA & 28.0 & 11.4 & .54 & 72.2 & & & 5.7 \\
\hline & & & FA & 27.0 & 11.5 & .52 & 72.2 & 51 & .77 & 5.6 \\
\hline & & & RA & 31.0 & 12.0 & .59 & 72.2 & & & 5.7 \\
\hline \multirow[t]{3}{*}{1,514} & RBI & 13:08 & UFA & 47.0 & 23.9 & .14 & 174 & & & 4.5 \\
\hline & & & FA & 47.0 & 23.9 & .26 & 174 & 27 & .97 & 4.5 \\
\hline & & & $\mathrm{RA}$ & 46.0 & 22.5 & .21 & 174 & & & 4.4 \\
\hline \multirow[t]{3}{*}{1,564} & $S$ & $12: 56$ & UFA & 33.0 & 12.1 & .65 & 79.6 & & & 5.8 \\
\hline & & & FA & 32.0 & 12.7 & .65 & 79.6 & 50 & .29 & 5.5 \\
\hline & & & RA & 32.0 & 12.6 & .67 & 79.6 & & & 5.3 \\
\hline \multirow[t]{3}{*}{1,725} & S & 12:49 & UFA & 29.0 & 12.3 & .61 & 76.1 & & & 5.3 \\
\hline & & & FA & 33.0 & 13.0 & .58 & 76.1 & 50 & .78 & 5.4 \\
\hline & & & RA & 33.0 & 13.0 & .61 & 76.1 & & & 5.5 \\
\hline \multirow[t]{2}{*}{1,734} & RBI & $12: 47$ & FA & 40.0 & 17.5 & .33 & 136 & 12 & .74 & 3.8 \\
\hline & & & $\mathrm{RA}$ & 42.0 & 19.0 & .33 & 136 & & & 3.9 \\
\hline \multirow[t]{3}{*}{1,753} & $S$ & $12: 43$ & UFA & 32.0 & 13.6 & .44 & 90.1 & & & 5.0 \\
\hline & & & FA & 32.0 & 13.5 & .57 & 90.1 & 43 & .79 & 4.9 \\
\hline & & & RA & 33.0 & 13.6 & .54 & 90.1 & & & 5.3 \\
\hline \multirow[t]{3}{*}{1,758} & LBI & $12: 40$ & UFA & 29.0 & 11.3 & .29 & 67.5 & & & 5.4 \\
\hline & & & FA & 29.0 & 11.1 & .59 & 67.5 & 46 & .78 & 5.3 \\
\hline & & & $\mathrm{RA}$ & 32.0 & 10.9 & .56 & 67.5 & & & 5.1 \\
\hline \multirow[t]{3}{*}{1,841} & $S$ & $12: 30$ & UFA & 32.0 & 13.3 & .58 & 90.4 & & & 5.1 \\
\hline & & & FA & 31.0 & 13.9 & .52 & 90.4 & 42 & .25 & 4.9 \\
\hline & & & RA & 29.0 & 14.0 & .48 & 90.4 & & & 5.0 \\
\hline \multirow[t]{2}{*}{1,847} & RBI & $12: 25$ & FA & 38.5 & 15.0 & .29 & 133 & 18 & .75 & 3.8 \\
\hline & & & $\mathrm{RA}$ & 40.5 & 15.5 & .39 & 133 & & & 3.9 \\
\hline \multirow[t]{3}{*}{1,947} & $S$ & $12: 17$ & UFA & 34.0 & 14.2 & .53 & 95.7 & & & 4.8 \\
\hline & & & FA & 34.0 & 13.0 & .49 & 95.7 & 39 & .80 & 4.8 \\
\hline & & & $\mathrm{RA}$ & 34.0 & 14.0 & .50 & 95.7 & & & 4.9 \\
\hline
\end{tabular}


Table 2. Chemical analyses for major ions in water samples from American Fork, October 1999, and Mary Ellen Gulch, Utah, September 2000.-Continued

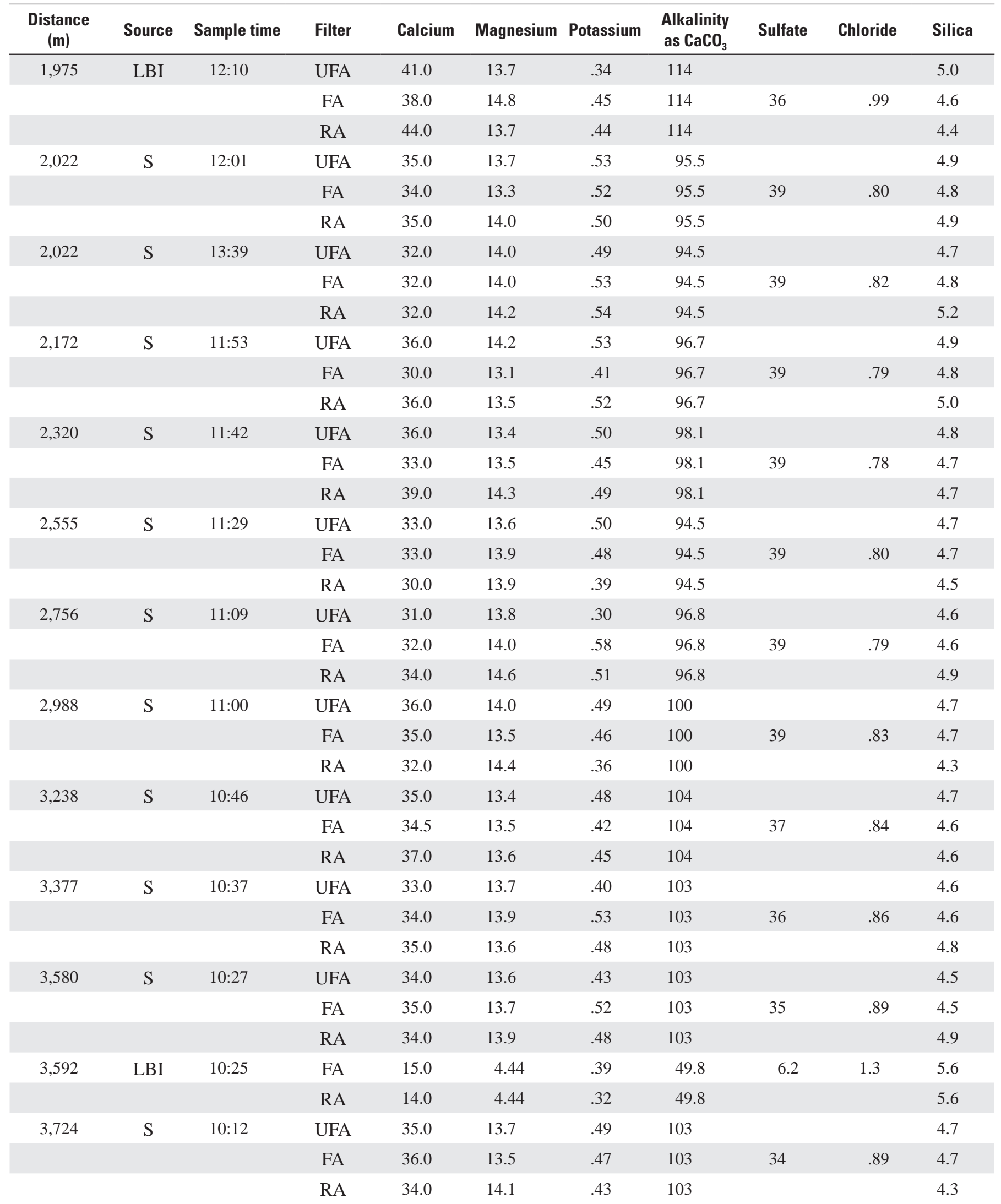


Table 2. Chemical analyses for major ions in water samples from American Fork, October 1999, and Mary Ellen Gulch, Utah, September 2000.-Continued

\begin{tabular}{|c|c|c|c|c|c|c|c|c|c|c|}
\hline $\begin{array}{c}\text { Distance } \\
(\mathbf{m})\end{array}$ & Source & Sample time & Filter & Calcium & Magnesium & Potassium & $\begin{array}{l}\text { Alkalinity } \\
\text { as } \mathrm{CaCO}_{3}\end{array}$ & Sulfate & Chloride & Silica \\
\hline \multirow[t]{3}{*}{3,974} & $S$ & 10:02 & UFA & 38.0 & 13.3 & .52 & 104 & & & 4.9 \\
\hline & & & FA & 34.0 & 13.0 & .39 & 104 & 34 & .92 & 4.4 \\
\hline & & & RA & 31.0 & 13.1 & .42 & 104 & & & 3.7 \\
\hline \multirow[t]{3}{*}{4,276} & S & 9:46 & UFA & 34.0 & 12.5 & .38 & 106 & & & 4.4 \\
\hline & & & FA & 34.0 & 13.7 & .49 & 106 & 34 & .88 & 4.6 \\
\hline & & & RA & 37.0 & 13.2 & .47 & 106 & & & 4.9 \\
\hline \multirow[t]{3}{*}{4,600} & S & $9: 30$ & UFA & 38.0 & 13.9 & .48 & 104 & 34 & .95 & 4.6 \\
\hline & & & FA & 34.0 & 14.1 & .46 & 104 & & & 4.5 \\
\hline & & & RA & 37.0 & 13.7 & .38 & 104 & & & 4.7 \\
\hline \multirow[t]{3}{*}{4,603} & LBI & $12: 40$ & UFA & 40.0 & 17.7 & .55 & 147 & & & 4.5 \\
\hline & & & FA & 39.0 & 18.0 & .55 & 147 & 14 & 1.0 & 4.4 \\
\hline & & & RA & 39.5 & 18.5 & .53 & 147 & & & 4.4 \\
\hline \multirow[t]{3}{*}{4,713} & S & $12: 55$ & UFA & 38.5 & 17.0 & .48 & 139 & & & 4.4 \\
\hline & & & FA & 38.0 & 17.4 & .55 & 139 & 18 & 1.0 & 4.4 \\
\hline & & & RA & 38.0 & 17.1 & .53 & 139 & & & 4.2 \\
\hline \multirow[t]{3}{*}{4,765} & S & $13: 10$ & UFA & 38.0 & 16.8 & .55 & 140 & & & 4.5 \\
\hline & & & FA & 36.0 & 16.6 & .44 & 140 & 18 & 1.0 & 4.4 \\
\hline & & & RA & 38.0 & 17.5 & .59 & 140 & & & 4.2 \\
\hline \multirow[t]{3}{*}{4,863} & $S$ & $13: 25$ & UFA & 36.0 & 16.6 & .47 & 139 & & & 4.6 \\
\hline & & & FA & 37.0 & 17.7 & .52 & 139 & 18 & 1.1 & 4.4 \\
\hline & & & RA & 36.0 & 17.8 & .47 & 139 & & & 4.5 \\
\hline \multirow[t]{3}{*}{5,030} & S & $13: 40$ & UFA & 40.0 & 16.6 & .57 & 140 & & & 4.6 \\
\hline & & & FA & 38.0 & 16.7 & .52 & 140 & 18 & .98 & 4.4 \\
\hline & & & RA & 34.0 & 17.0 & .53 & 140 & & & 4.5 \\
\hline
\end{tabular}


Table 3. Chemical analyses of trace elements in water samples from American Fork, October 1999, and Mary Ellen Gulch, Utah, September 2000.

[Distance from injection, in meters (m). Source: S, stream; RBI, right-bank inflow; LBI, left-bank inflow. Filter, UFA, 10,000 Dalton ultra-filter, FA,

0.45-micrometer; RA, unfiltered. Al, aluminum; As, arsenic; Ba, barium; Cd, cadmium; $\mathrm{Cu}$, copper; Fe, iron; $\mathrm{Pb}$, lead; Li, lithium; Mn, manganese; Ni, nickel; Sr, strontium; Zn, zinc; <, less than; MS, missing sample; NA, not analyzed; all concentrations in milligrams per liter]

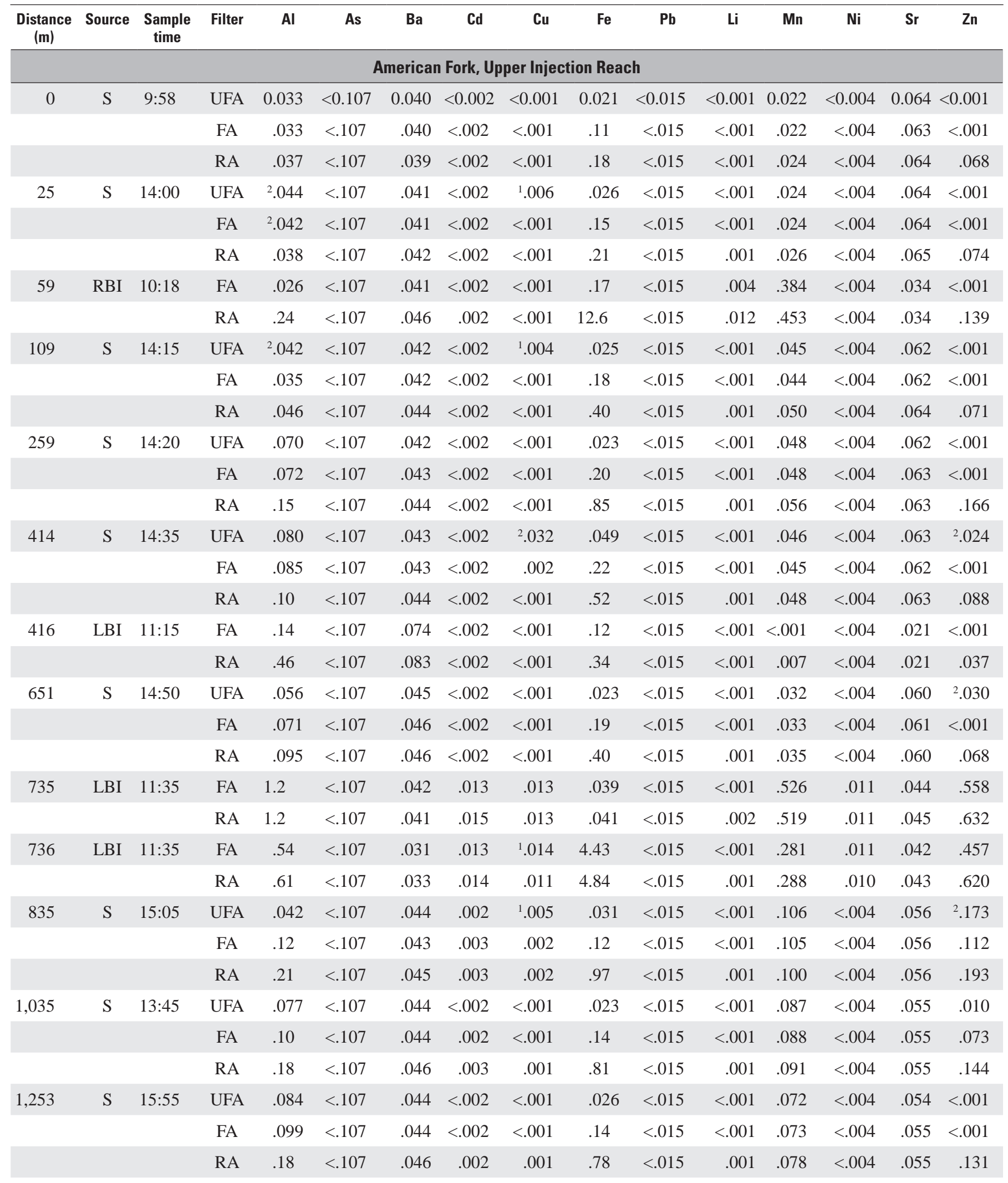


Table 3. Chemical analyses of trace elements in water samples from American Fork, October 1999, and Mary Ellen Gulch, Utah, September 2000.-Continued

\begin{tabular}{|c|c|c|c|c|c|c|c|c|c|c|c|c|c|c|c|}
\hline $\begin{array}{c}\text { Distance } \\
(\mathrm{m})\end{array}$ & Source & $\begin{array}{c}\text { Sample } \\
\text { time }\end{array}$ & Filter & Al & As & $\mathrm{Ba}$ & Cd & $\mathrm{Cu}$ & $\mathrm{Fe}$ & $\mathrm{Pb}$ & Li & Mn & $\mathrm{Ni}$ & Sr & $\mathrm{Zn}$ \\
\hline \multirow[t]{2}{*}{1,603} & $S$ & $16: 20$ & UFA & .073 & $<.107$ & .047 & $<.002$ & $<.001$ & .023 & $<.015$ & $<.001$ & .050 & $<.004$ & .053 & $<.001$ \\
\hline & & & RA & .16 & $<.107$ & .050 & .002 & .001 & .66 & $<.015$ & .001 & .057 & $<.004$ & .055 & .163 \\
\hline \multirow[t]{2}{*}{2,003} & $\mathrm{~S}$ & $16: 35$ & UFA & .056 & $<.107$ & .050 & $<.002$ & ${ }^{1} .007$ & .025 & $<.015$ & $<.001$ & .019 & $<.004$ & .054 & ${ }^{2} .053$ \\
\hline & & & RA & .081 & $<.107$ & .049 & $<.002$ & $<.001$ & .26 & $<.015$ & .001 & .021 & $<.004$ & .053 & .075 \\
\hline \multicolumn{16}{|c|}{ American Fork, Lower Injection Reach } \\
\hline \multirow[t]{2}{*}{2,983} & $\mathrm{~S}$ & $15: 10$ & UFA & ${ }^{2} .042$ & $<.107$ & .053 & $<.002$ & $<.001$ & .024 & $<.015$ & $<.001$ & .010 & $<.004$ & .046 & ${ }^{2} .020$ \\
\hline & & & FA & .031 & $<.107$ & .057 & $<.002$ & $<.001$ & .053 & $<.015$ & .001 & .011 & $<.004$ & .048 & ${ }^{2} .034$ \\
\hline 3,123 & & & RA & .13 & $<.107$ & .057 & $<.002$ & $<.001$ & .19 & $<.015$ & .742 & .022 & $<.004$ & .048 & .089 \\
\hline \multirow[t]{2}{*}{3,128} & LBI & $15: 00$ & FA & $<.021$ & $<.107$ & .025 & $<.002$ & $<.001$ & .016 & $<.015$ & $<.001$ & $<.001$ & $<.004$ & .026 & ${ }^{2} .026$ \\
\hline & & & RA & $<.021$ & $<.107$ & .027 & $<.002$ & $<.001$ & .013 & $<.015$ & $<.001$ & $<.001$ & $<.004$ & .027 & $<.001$ \\
\hline \multirow[t]{2}{*}{3,198} & LBI & $14: 55$ & FA & .022 & $<.107$ & .025 & $<.002$ & $<.001$ & .061 & $<.015$ & $<.001$ & .005 & $<.004$ & .027 & .048 \\
\hline & & & RA & .033 & $<.107$ & .023 & $<.002$ & $<.001$ & .070 & $<.015$ & $<.001$ & .005 & $<.004$ & .027 & .057 \\
\hline \multirow[t]{2}{*}{3,303} & LBI & $14: 50$ & FA & .023 & $<.107$ & .030 & $<.002$ & $<.001$ & .22 & $<.015$ & $<.001$ & .075 & $<.004$ & .028 & ${ }^{2} .038$ \\
\hline & & & $\mathrm{RA}$ & .063 & $<.107$ & .034 & $<.002$ & $<.001$ & .46 & $<.015$ & $<.001$ & .084 & $<.004$ & .028 & $<.001$ \\
\hline 3,331 & LBI & $14: 45$ & FA & .025 & $<.107$ & .028 & $<.002$ & ${ }^{1} .003$ & .12 & $<.015$ & .001 & .032 & $<.004$ & .032 & ${ }^{2} .040$ \\
\hline 3,345 & & & RA & .14 & $<.107$ & .115 & .008 & .023 & 4.30 & .027 & .001 & .363 & .004 & .061 & 1.14 \\
\hline \multirow[t]{2}{*}{3,385} & LBI & $14: 30$ & FA & .023 & $<.107$ & .031 & $<.002$ & $<.001$ & .068 & $<.015$ & .001 & .025 & $<.004$ & .035 & .057 \\
\hline & & & RA & .12 & $<.107$ & .033 & $<.002$ & $<.001$ & .23 & $<.015$ & .001 & .047 & $<.004$ & .035 & .076 \\
\hline \multirow[t]{3}{*}{3,470} & $S$ & $14: 20$ & UFA & ${ }^{2} .038$ & $<.107$ & .042 & $<.002$ & $<.001$ & .024 & $<.015$ & .365 & .014 & $<.004$ & .039 & $<.001$ \\
\hline & & & FA & .027 & $<.107$ & .044 & $<.002$ & $<.001$ & .062 & $<.015$ & .359 & .017 & $<.004$ & .039 & ${ }^{2} .080$ \\
\hline & & & $\mathrm{RA}$ & .071 & $<.107$ & .050 & $<.002$ & $<.001$ & .14 & $<.015$ & .366 & .019 & $<.004$ & .039 & .003 \\
\hline \multirow[t]{3}{*}{3,475} & RBI & $14: 15$ & UFA & ${ }^{2} .047$ & $<.107$ & .126 & .006 & ${ }^{2} .037$ & ${ }^{2} .051$ & $<.015$ & $<.001$ & .124 & $<.004$ & .063 & ${ }^{2} .640$ \\
\hline & & & FA & .022 & $<.107$ & .125 & .006 & $<.001$ & .022 & $<.015$ & .002 & .119 & $<.004$ & .063 & .687 \\
\hline & & & RA & .28 & $<.107$ & .193 & .008 & .016 & 1.66 & .738 & .001 & .125 & $<.004$ & .065 & 1.02 \\
\hline \multirow[t]{2}{*}{3,485} & RBI & $14: 10$ & FA & .030 & $<.107$ & .099 & .006 & .004 & .017 & $<.015$ & .002 & .008 & $<.004$ & .065 & .521 \\
\hline & & & RA & .21 & $<.107$ & .865 & .011 & .041 & 3.01 & 1.88 & .001 & .010 & $<.004$ & .079 & 1.26 \\
\hline \multirow[t]{3}{*}{3,625} & S & $14: 00$ & UFA & ${ }^{2} .036$ & $<.107$ & .045 & $<.002$ & $<.001$ & .022 & $<.015$ & .347 & .014 & $<.004$ & .039 & $<.001$ \\
\hline & & & FA & .024 & $<.107$ & .047 & $<.002$ & .003 & .058 & $<.015$ & .349 & .015 & $<.004$ & .040 & ${ }^{2} .091$ \\
\hline & & & RA & .056 & $<.107$ & .056 & $<.002$ & $<.001$ & .18 & .033 & .351 & .015 & $<.004$ & .040 & .053 \\
\hline
\end{tabular}


Table 3. Chemical analyses of trace elements in water samples from American Fork, October 1999, and Mary Ellen Gulch, Utah, September 2000.-Continued

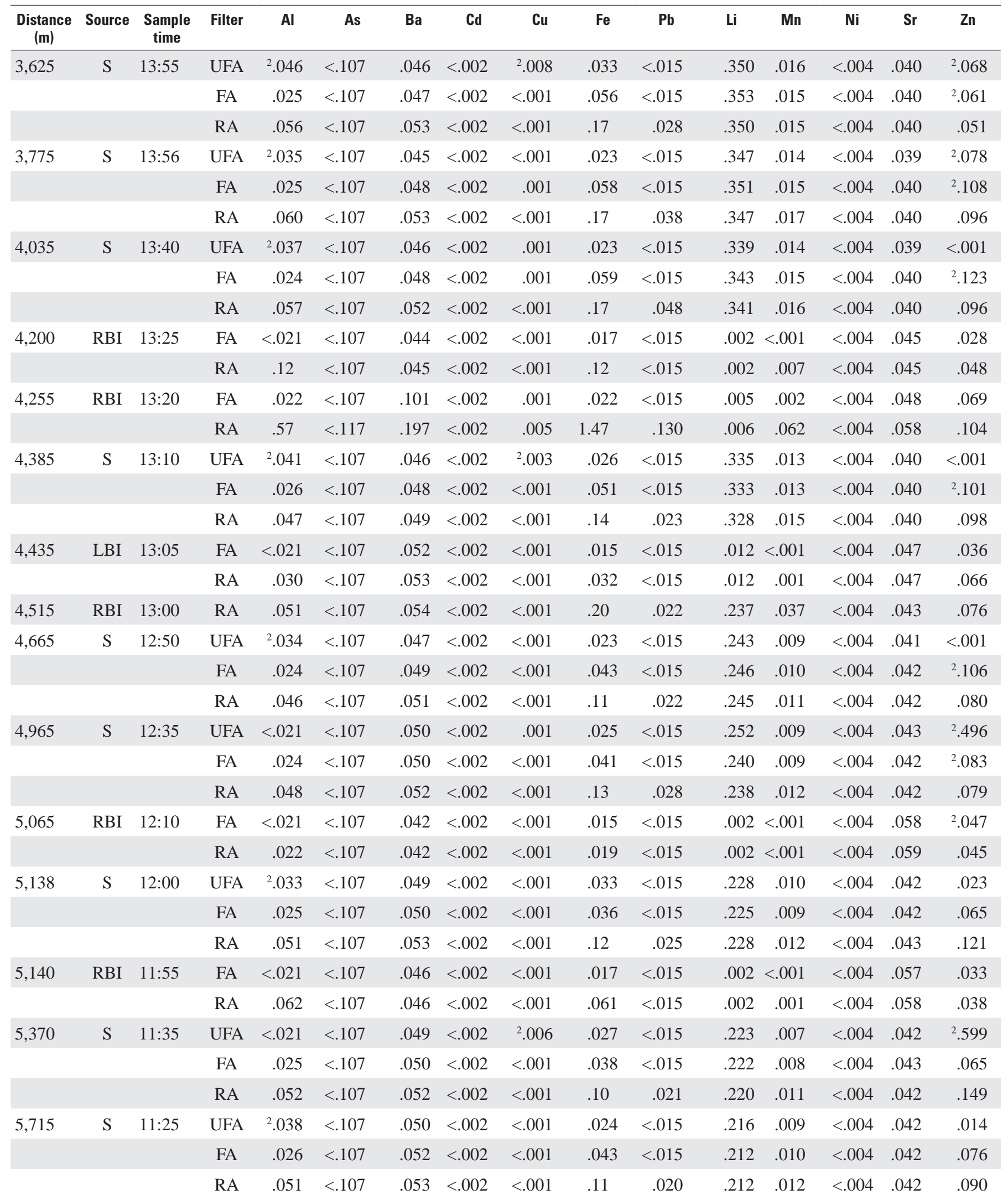


Table 3. Chemical analyses of trace elements in water samples from American Fork, October 1999, and Mary Ellen Gulch, Utah, September 2000.-Continued

\begin{tabular}{|c|c|c|c|c|c|c|c|c|c|c|c|c|c|c|c|}
\hline $\begin{array}{c}\text { Distance } \\
(\mathbf{m})\end{array}$ & Source & $\begin{array}{c}\text { Sample } \\
\text { time }\end{array}$ & Filter & Al & As & $\mathrm{Ba}$ & Cd & Cu & $\mathrm{Fe}$ & $\mathrm{Pb}$ & Li & Mn & $\mathrm{Ni}$ & $\mathrm{Sr}$ & $\mathrm{Zn}$ \\
\hline \multirow[t]{2}{*}{6,065} & $S$ & $11: 05$ & UFA & $<.021$ & $<.107$ & .053 & $<.002$ & ${ }^{2} .007$ & .031 & $<.015$ & .217 & .014 & $<.004$ & .043 & ${ }^{2} .733$ \\
\hline & & & RA & .056 & $<.107$ & .055 & $<.002$ & $<.001$ & .12 & .029 & .209 & .015 & $<.004$ & .043 & .100 \\
\hline \multirow[t]{2}{*}{6,275} & S & $17: 15$ & UFA & $<.021$ & $<.107$ & .055 & $<.002$ & .001 & .023 & ${ }^{2} .020$ & .204 & .008 & $<.004$ & .044 & ${ }^{2} .540$ \\
\hline & & & $\mathrm{RA}$ & .052 & $<.107$ & .057 & $<.002$ & $<.001$ & .11 & .023 & .198 & .013 & $<.004$ & .043 & .065 \\
\hline \multirow[t]{3}{*}{6,275} & $\mathrm{~S}$ & $10: 55$ & UFA & $<.021$ & $<.107$ & .052 & $<.002$ & .001 & .022 & $<.015$ & .212 & .010 & $<.004$ & .044 & ${ }^{2} .464$ \\
\hline & & & FA & .024 & $<.107$ & .052 & $<.002$ & $<.001$ & .044 & $<.015$ & .203 & .011 & $<.004$ & .043 & .066 \\
\hline & & & RA & .059 & $<.107$ & .055 & $<.002$ & $<.001$ & .14 & .021 & .204 & .015 & $<.004$ & .043 & .102 \\
\hline \multirow{2}{*}{6,452} & & & FA & .024 & $<.107$ & .051 & $<.002$ & $<.001$ & .041 & $<.015$ & .166 & .009 & $<.004$ & .043 & .075 \\
\hline & & & RA & .072 & $<.107$ & .055 & $<.002$ & $<.001$ & .15 & .030 & .168 & .014 & $<.004$ & .044 & .136 \\
\hline \multirow[t]{3}{*}{6,717} & $\mathrm{~S}$ & $10: 25$ & UFA & $<.021$ & $<.107$ & .050 & $<.002$ & .001 & .25 & $<.015$ & .167 & .007 & $<.004$ & .044 & ${ }^{2} .644$ \\
\hline & & & FA & .026 & $<.107$ & .051 & $<.002$ & $<.001$ & .035 & $<.015$ & .163 & .008 & $<.004$ & .043 & .073 \\
\hline & & & RA & .20 & $<.107$ & .064 & $<.002$ & .002 & .36 & .071 & .165 & .028 & $<.004$ & .044 & .137 \\
\hline \multirow[t]{3}{*}{8,387} & $\mathrm{~S}$ & $16: 25$ & UFA & $<.021$ & $<.107$ & .535 & $<.002$ & ${ }^{2} .005$ & .024 & $<.015$ & .151 & .003 & $<.004$ & .046 & ${ }^{2} .343$ \\
\hline & & & FA & .027 & $<.107$ & .054 & $<.002$ & ${ }^{2} .002$ & .032 & $<.015$ & .152 & .004 & $<.004$ & .046 & .091 \\
\hline & & & RA & .043 & $<.107$ & .059 & $<.002$ & $<.001$ & .084 & $<.015$ & .156 & .005 & $<.004$ & .046 & .035 \\
\hline 8,507 & & & $\mathrm{RA}$ & .047 & $<.107$ & .059 & $<.002$ & $<.001$ & .092 & $<.015$ & .151 & .005 & $<.004$ & .047 & .036 \\
\hline \multirow[t]{3}{*}{10,287} & S & $13: 05$ & UFA & .035 & $<.107$ & .048 & $<.002$ & $<.001$ & .021 & $<.015$ & .085 & $<.001$ & $<.004$ & .102 & $<.001$ \\
\hline & & & FA & .035 & $<.107$ & .053 & $<.002$ & $<.001$ & .055 & $<.015$ & .094 & .002 & $<.004$ & .107 & ${ }^{2} .071$ \\
\hline & & & RA & .036 & $<.107$ & .052 & $<.002$ & $<.001$ & .047 & $<.015$ & .090 & $<.001$ & $<.004$ & .104 & .024 \\
\hline \multirow[t]{3}{*}{10,307} & RBI & $12: 45$ & UFA & .034 & $<.107$ & .044 & $<.002$ & ${ }^{2} .002$ & .024 & $<.015$ & $<.001$ & $<.001$ & $<.004$ & .272 & .032 \\
\hline & & & FA & $<.021$ & $<.107$ & .047 & $<.002$ & $<.001$ & .019 & $<.015$ & .002 & $<.001$ & $<.004$ & .279 & ${ }^{2} .084$ \\
\hline & & & RA & .033 & $<.107$ & .045 & $<.002$ & $<.001$ & .053 & $<.015$ & .001 & .001 & $<.004$ & .278 & .040 \\
\hline \multirow[t]{3}{*}{10,407} & $\mathrm{~S}$ & $12: 20$ & UFA & .035 & $<.107$ & .048 & $<.002$ & $<.001$ & .022 & $<.015$ & .082 & $<.001$ & $<.004$ & .104 & .031 \\
\hline & & & FA & .021 & $<.107$ & .049 & $<.002$ & $<.001$ & .024 & $<.015$ & .087 & .001 & $<.004$ & .105 & .068 \\
\hline & & & RA & .031 & $<.107$ & .053 & $<.002$ & $<.001$ & .045 & $<.015$ & .089 & $<.001$ & $<.004$ & .106 & .023 \\
\hline \multirow[t]{3}{*}{11,962} & $\mathrm{~S}$ & $11: 10$ & UFA & .030 & $<.107$ & .042 & $<.002$ & $<.001$ & .027 & $<.015$ & .036 & $<.001$ & $<.004$ & .981 & $<.001$ \\
\hline & & & FA & .023 & $<.107$ & .043 & $<.002$ & $<.001$ & .020 & $<.015$ & .037 & $<.001$ & $<.004$ & .981 & ${ }^{2} .059$ \\
\hline & & & RA & .027 & $<.107$ & .045 & $<.002$ & $<.001$ & .029 & $<.015$ & .036 & $<.001$ & $<.004$ & .978 & .008 \\
\hline
\end{tabular}


Table 3. Chemical analyses of trace elements in water samples from American Fork, October 1999, and Mary Ellen Gulch, Utah, September 2000.-Continued

\begin{tabular}{|c|c|c|c|c|c|c|c|c|c|c|c|c|c|c|c|}
\hline $\begin{array}{c}\text { Distance } \\
\text { (m) }\end{array}$ & Source & $\begin{array}{c}\text { Sample } \\
\text { time }\end{array}$ & Filter & Al & As & Ba & Cd & Cu & $\mathrm{Fe}$ & $\mathbf{P b}$ & Li & $\mathrm{Mn}$ & $\mathbf{N i}$ & $\mathrm{Sr}$ & $\mathrm{Zn}$ \\
\hline \multicolumn{16}{|c|}{ Mary Ellen Gulch } \\
\hline \multirow[t]{3}{*}{163} & S & $16: 12$ & UFA & 1.7 & $<.03$ & .022 & .002 & .300 & 1.05 & .019 & $<.001$ & .058 & .013 & .021 & .235 \\
\hline & & & FA & 1.8 & $<.03$ & .024 & .003 & .220 & 1.10 & .016 & $<.001$ & .056 & .015 & .020 & .200 \\
\hline & & & RA & 1.8 & $<.03$ & .024 & .002 & .200 & 1.40 & .009 & $<.001$ & .058 & .016 & .019 & .200 \\
\hline \multirow[t]{3}{*}{172} & S & $16: 10$ & UFA & 1.6 & $<.03$ & .020 & .002 & .200 & .910 & .015 & $<.001$ & .050 & .009 & .020 & ${ }^{1} .190$ \\
\hline & & & FA & 1.5 & $<.03$ & .018 & $<.001$ & .210 & .920 & $<.006$ & $<.001$ & .051 & .010 & .020 & ${ }^{1} .180$ \\
\hline & & & RA & 1.5 & $<.03$ & .021 & .002 & .180 & 1.20 & .012 & $<.001$ & .051 & .011 & .021 & .150 \\
\hline \multirow[t]{2}{*}{178} & RBI & $16: 10$ & FA & 2.9 & $<.03$ & .019 & .003 & .033 & 3.60 & .018 & $<.001$ & .074 & .018 & .023 & .230 \\
\hline & & & RA & 2.5 & $<.03$ & .018 & .002 & .029 & 4.15 & .010 & $<.001$ & .075 & .015 & .023 & .230 \\
\hline \multirow[t]{3}{*}{270} & S & $16: 00$ & UFA & 1.7 & $<.03$ & .020 & .002 & .180 & .470 & .012 & $<.001$ & .059 & .011 & .019 & ${ }^{2} .215$ \\
\hline & & & FA & 1.6 & $<.03$ & .025 & .002 & .170 & .465 & .008 & $<.001$ & .056 & .012 & .020 & ${ }^{2} .190$ \\
\hline & & & RA & 1.8 & $<.03$ & .022 & .003 & .150 & .490 & $<.006$ & $<.001$ & .047 & .014 & .020 & .180 \\
\hline \multirow[t]{3}{*}{370} & $S$ & $15: 50$ & UFA & 1.7 & $<.03$ & .031 & .002 & .210 & .190 & .014 & $<.001$ & .068 & .012 & .021 & ${ }^{2} .195$ \\
\hline & & & FA & 1.5 & $<.03$ & .023 & $<.001$ & .200 & .185 & .013 & $<.001$ & .059 & .014 & .021 & .165 \\
\hline & & & RA & 1.7 & $<.03$ & .033 & .003 & .160 & .185 & $<.006$ & $<.001$ & .056 & .013 & .017 & .190 \\
\hline \multirow[t]{2}{*}{397} & RBI & $15: 50$ & FA & $<.080$ & $<.03$ & .026 & $<.001$ & .014 & .014 & $<.006$ & $<.001$ & .001 & $<.002$ & .044 & .010 \\
\hline & & & RA & $<.080$ & $<.03$ & .032 & $<.001$ & .005 & .061 & $<.006$ & $<.001$ & .005 & $<.002$ & .046 & .006 \\
\hline \multirow[t]{3}{*}{447} & $\mathrm{~S}$ & $15: 42$ & UFA & 1.9 & $<.03$ & .026 & .002 & .200 & .145 & .012 & $<.001$ & .062 & .012 & .024 & .180 \\
\hline & & & FA & 1.7 & $<.03$ & .027 & .002 & .180 & .165 & .015 & $<.001$ & .060 & .009 & .022 & .190 \\
\hline & & & RA & 1.9 & $<.03$ & .026 & .002 & .190 & .175 & .016 & $<.001$ & .054 & .011 & .024 & .170 \\
\hline \multirow[t]{2}{*}{488} & RBI & $15: 40$ & FA & $<.080$ & $<.03$ & .027 & $<.001$ & .003 & .013 & $<.006$ & $<.001$ & $<.001$ & $<.002$ & .039 & .012 \\
\hline & & & RA & .093 & $<.03$ & .022 & $<.001$ & .008 & .083 & $<.006$ & $<.001$ & .004 & $<.002$ & .039 & .012 \\
\hline \multirow[t]{3}{*}{540} & $S$ & $15: 33$ & UFA & .160 & $<.03$ & .022 & $<.001$ & .030 & .010 & $<.006$ & $<.001$ & .022 & .004 & .033 & ${ }^{1} .055$ \\
\hline & & & FA & .220 & $<.03$ & .026 & $<.001$ & .021 & .009 & $<.006$ & $<.001$ & .020 & .003 & .034 & .039 \\
\hline & & & RA & .620 & $<.03$ & .026 & $<.001$ & .064 & .061 & $<.006$ & $<.001$ & .021 & .004 & .035 & .055 \\
\hline \multirow[t]{2}{*}{633} & RBI & $15: 30$ & UFA & $<.080$ & $<.03$ & .029 & $<.001$ & .015 & .008 & $<.006$ & $<.001$ & .001 & $<.002$ & .040 & ${ }^{2} .020$ \\
\hline & & & FA & $<.080$ & $<.03$ & .030 & $<.001$ & $<.001$ & .015 & $<.006$ & $<.001$ & $<.001$ & $<.002$ & .037 & ${ }^{2} .019$ \\
\hline 633 & RBI & $15: 30$ & RA & $<.080$ & $<.03$ & .028 & $<.001$ & .002 & $<.008$ & $<.006$ & $<.001$ & $<.001$ & $<.002$ & .041 & .010 \\
\hline \multirow[t]{3}{*}{685} & $S$ & $15: 23$ & UFA & MS & MS & MS & MS & MS & MS & MS & MS & MS & MS & MS & MS \\
\hline & & & FA & .240 & $<.03$ & .026 & $<.001$ & .013 & $<.008$ & $<.006$ & $<.001$ & .011 & $<.002$ & .036 & .018 \\
\hline & & & RA & .350 & $<.03$ & .021 & $<.001$ & .026 & .032 & $<.006$ & $<.001$ & .010 & .002 & .035 & .028 \\
\hline \multirow[t]{3}{*}{735} & S & $15: 20$ & UFA & .190 & $<.03$ & .027 & $<.001$ & $<.001$ & .013 & $<.006$ & $<.001$ & .010 & $<.002$ & .033 & .028 \\
\hline & & & FA & .190 & $<.03$ & .027 & $<.001$ & .017 & .010 & .009 & $<.001$ & .010 & .003 & .035 & .021 \\
\hline & & & RA & .320 & $<.03$ & .028 & $<.001$ & .008 & .029 & $<.006$ & $<.001$ & .009 & $<.002$ & .031 & .027 \\
\hline \multirow[t]{3}{*}{758} & $S$ & $15: 12$ & UFA & .160 & $<.03$ & .028 & .001 & .008 & $<.008$ & $<.006$ & $<.001$ & .008 & .002 & .035 & .057 \\
\hline & & & FA & .180 & $<.03$ & .028 & $<.001$ & .010 & .020 & $<.006$ & $<.001$ & .008 & $<.002$ & .036 & .048 \\
\hline & & & RA & .280 & $<.03$ & .028 & $<.001$ & .017 & .026 & $<.006$ & $<.001$ & .007 & $<.002$ & .034 & .054 \\
\hline \multirow[t]{2}{*}{760} & RBI & $15: 10$ & FA & $<.080$ & $<.03$ & .061 & $<.001$ & .004 & .010 & $<.006$ & $<.001$ & $<.001$ & $<.002$ & .035 & .009 \\
\hline & & & RA & $<.080$ & $<.03$ & .050 & $<.001$ & $<.001$ & .031 & $<.006$ & $<.001$ & .002 & $<.002$ & .030 & .006 \\
\hline
\end{tabular}


Table 3. Chemical analyses of trace elements in water samples from American Fork, October 1999, and Mary Ellen Gulch, Utah, September 2000.-Continued

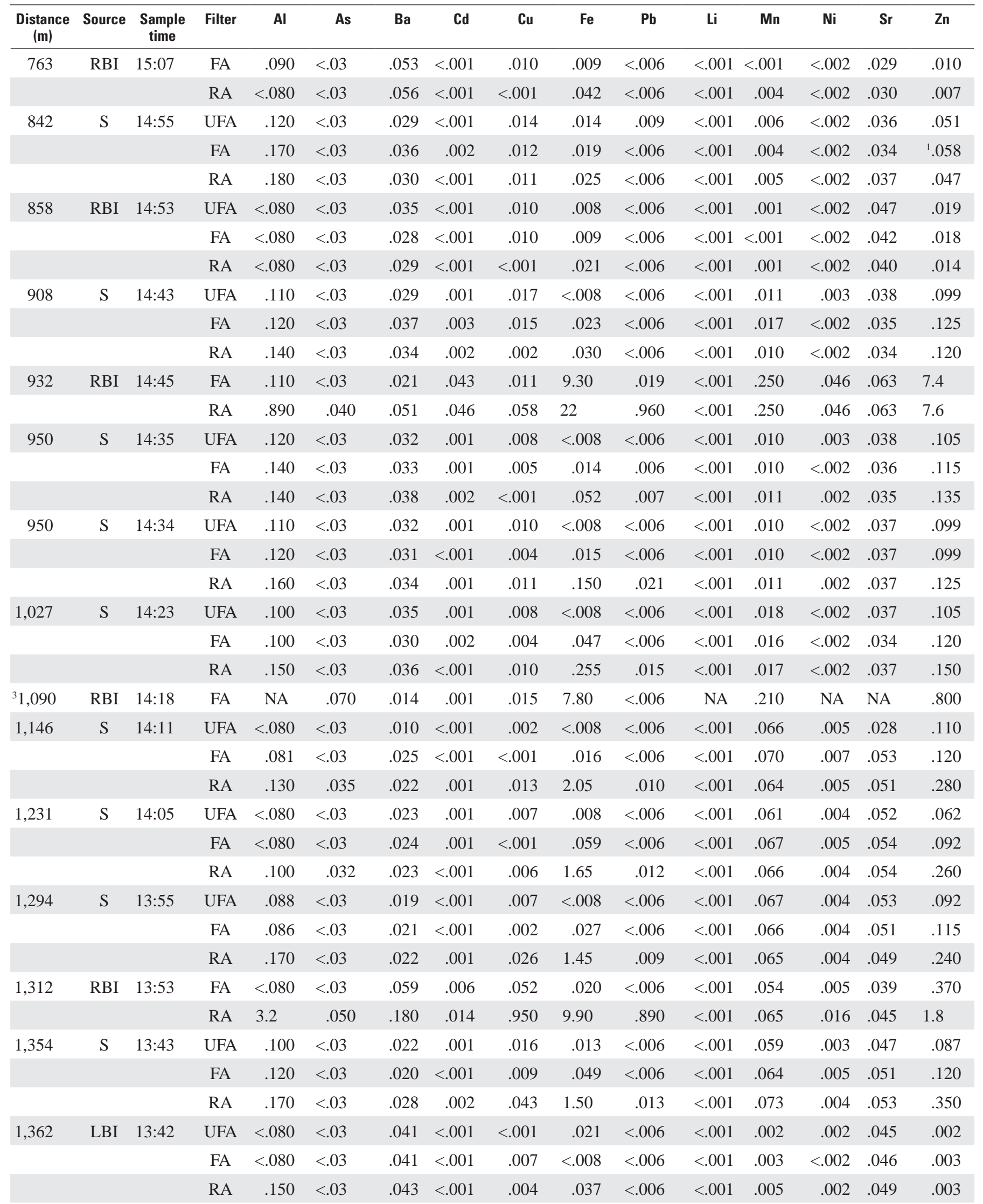


Table 3. Chemical analyses of trace elements in water samples from American Fork, October 1999, and Mary Ellen Gulch, Utah, September 2000.-Continued

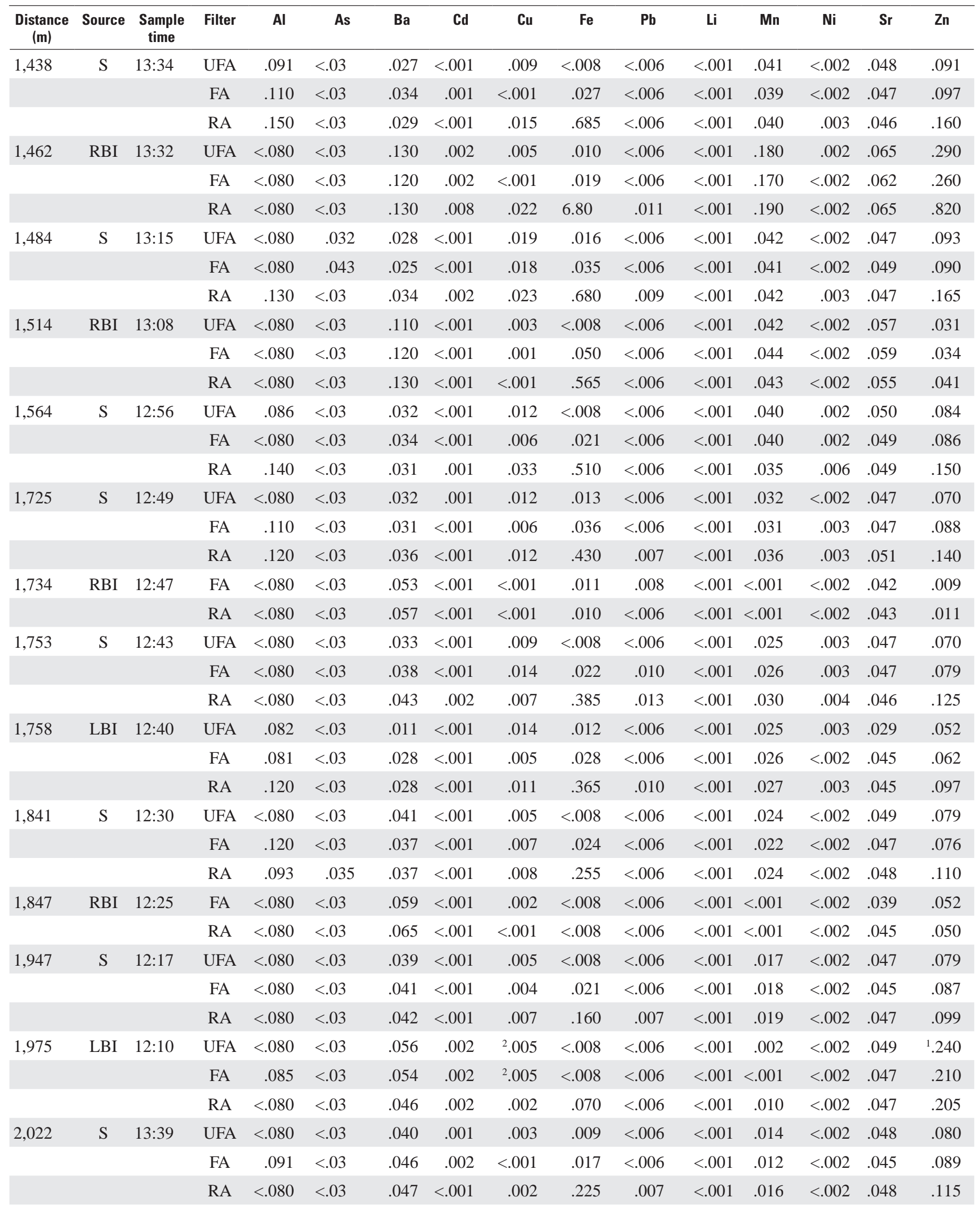


Table 3. Chemical analyses of trace elements in water samples from American Fork, October 1999, and Mary Ellen Gulch, Utah, September 2000.-Continued

\begin{tabular}{|c|c|c|c|c|c|c|c|c|c|c|c|c|c|c|c|}
\hline $\begin{array}{c}\text { Distance } \\
\text { (m) }\end{array}$ & Source & $\begin{array}{c}\text { Sample } \\
\text { time }\end{array}$ & Filter & Al & As & $\mathrm{Ba}$ & Cd & Cu & $\mathrm{Fe}$ & $\mathbf{P b}$ & Li & Mn & $\mathrm{Ni}$ & Sr & $\mathrm{Zn}$ \\
\hline \multirow[t]{3}{*}{2,022} & $\mathrm{~S}$ & $12: 01$ & UFA & $<.080$ & $<.03$ & .046 & $<.001$ & .004 & $<.008$ & $<.006$ & $<.001$ & .017 & $<.002$ & .048 & .086 \\
\hline & & & FA & $<.080$ & $<.03$ & .041 & $<.001$ & .004 & .022 & $<.006$ & $<.001$ & .016 & $<.002$ & .046 & .090 \\
\hline & & & RA & $<.080$ & $<.03$ & .044 & .001 & .007 & .180 & $<.006$ & $<.001$ & .018 & .004 & .048 & .105 \\
\hline \multirow[t]{3}{*}{2,172} & S & $11: 53$ & UFA & $<.080$ & $<.03$ & .042 & $<.001$ & ${ }^{2} .009$ & .013 & $<.006$ & $<.001$ & .015 & .003 & .048 & .081 \\
\hline & & & FA & $<.080$ & .031 & .038 & $<.001$ & .005 & .024 & $<.006$ & $<.001$ & .015 & $<.002$ & .046 & .100 \\
\hline & & & RA & $<.080$ & $<.03$ & .043 & $<.001$ & .005 & .150 & $<.006$ & $<.001$ & .016 & $<.002$ & .050 & .110 \\
\hline \multirow[t]{3}{*}{2,320} & S & $11: 42$ & UFA & $<.080$ & $<.03$ & .042 & .002 & ${ }^{2} .014$ & .015 & $<.006$ & $<.001$ & .013 & $<.002$ & .045 & .093 \\
\hline & & & FA & $<.080$ & $<.03$ & .041 & $<.001$ & .006 & .021 & $<.006$ & $<.001$ & .014 & $<.002$ & .043 & .091 \\
\hline & & & RA & $<.080$ & $<.03$ & .036 & $<.001$ & .010 & .180 & .008 & $<.001$ & .014 & $<.002$ & .049 & .098 \\
\hline \multirow[t]{3}{*}{2,555} & $S$ & $11: 29$ & UFA & $<.080$ & $<.03$ & .042 & .001 & $<.001$ & .014 & $<.006$ & $<.001$ & .010 & $<.002$ & .044 & .100 \\
\hline & & & FA & $<.080$ & $<.03$ & .043 & $<.001$ & $<.001$ & .016 & .007 & $<.001$ & .009 & .003 & .046 & .090 \\
\hline & & & RA & .097 & $<.03$ & .040 & $<.001$ & .003 & .130 & $<.006$ & $<.001$ & .010 & $<.002$ & .044 & .110 \\
\hline \multirow[t]{3}{*}{2,756} & $S$ & 11:09 & UFA & $<.080$ & $<.03$ & .042 & .001 & $<.001$ & .014 & $<.006$ & $<.001$ & .007 & $<.002$ & .042 & .071 \\
\hline & & & FA & $<.080$ & $<.03$ & .043 & $<.001$ & $<.001$ & .013 & .008 & $<.001$ & .007 & .004 & .046 & .082 \\
\hline & & & RA & .086 & $<.03$ & .049 & $<.001$ & $<.001$ & .245 & .007 & $<.001$ & .012 & $<.002$ & .042 & .125 \\
\hline \multirow[t]{3}{*}{2,988} & $S$ & $11: 00$ & UFA & $<.080$ & $<.03$ & .043 & $<.001$ & .002 & $<.008$ & $<.006$ & $<.001$ & .005 & $<.002$ & .046 & .076 \\
\hline & & & FA & $<.080$ & $<.03$ & .041 & .001 & .007 & .013 & $<.006$ & $<.001$ & .006 & .002 & .047 & .084 \\
\hline & & & RA & .081 & $<.03$ & .044 & $<.001$ & $<.001$ & .150 & .012 & $<.001$ & .007 & $<.002$ & .039 & .110 \\
\hline \multirow[t]{3}{*}{3,238} & $S$ & $10: 46$ & UFA & $<.080$ & $<.03$ & .043 & $<.001$ & ${ }^{2} .006$ & $<.008$ & $<.006$ & $<.001$ & .004 & $<.002$ & .047 & .064 \\
\hline & & & FA & $<.080$ & $<.03$ & .037 & .001 & ${ }^{2} .008$ & .017 & $<.006$ & $<.001$ & .004 & $<.002$ & .043 & .079 \\
\hline & & & RA & .097 & $<.03$ & .043 & .001 & .004 & .125 & $<.006$ & $<.001$ & .005 & .003 & .045 & .100 \\
\hline \multirow[t]{3}{*}{3,377} & $S$ & $10: 37$ & UFA & $<.080$ & $<.03$ & .045 & .001 & $<.001$ & .014 & $<.006$ & $<.001$ & .003 & $<.002$ & .044 & .125 \\
\hline & & & FA & $<.080$ & $<.03$ & .046 & $<.001$ & .001 & .015 & .014 & $<.001$ & .003 & $<.002$ & .047 & .105 \\
\hline & & & RA & $<.080$ & $<.03$ & .051 & .001 & $<.001$ & .115 & $<.006$ & $<.001$ & .005 & .002 & .045 & .110 \\
\hline \multirow[t]{3}{*}{3,580} & $S$ & $10: 27$ & UFA & $<.080$ & $<.03$ & .044 & $<.001$ & $<.001$ & .014 & $<.006$ & $<.001$ & .002 & $<.002$ & .043 & ${ }^{2} .160$ \\
\hline & & & FA & $<.080$ & $<.03$ & .046 & $<.001$ & $<.001$ & .010 & .008 & $<.001$ & .002 & $<.002$ & .047 & .135 \\
\hline & & & RA & $<.080$ & $<.03$ & .048 & .001 & .011 & .130 & .011 & $<.001$ & .005 & $<.002$ & .046 & .098 \\
\hline \multirow[t]{2}{*}{3,592} & LBI & $10: 25$ & FA & .099 & $<.03$ & .058 & $<.001$ & .005 & .039 & $<.006$ & $<.001$ & .001 & $<.002$ & .037 & ${ }^{2} .036$ \\
\hline & & & RA & $<.080$ & $<.03$ & .059 & $<.001$ & $<.001$ & .185 & $<.006$ & $<.001$ & .012 & $<.002$ & .034 & .013 \\
\hline \multirow[t]{3}{*}{3,724} & $S$ & $10: 12$ & UFA & $<.080$ & $<.03$ & .047 & $<.001$ & ${ }^{2} .007$ & .009 & $<.006$ & $<.001$ & .002 & $<.002$ & .049 & .076 \\
\hline & & & FA & $<.080$ & $<.03$ & .049 & $<.001$ & .002 & .010 & $<.006$ & $<.001$ & .001 & $<.002$ & .048 & .080 \\
\hline & & & RA & $<.080$ & $<.03$ & .044 & .001 & $<.001$ & .063 & $<.006$ & $<.001$ & .002 & $<.002$ & .042 & .085 \\
\hline \multirow[t]{3}{*}{3,974} & $S$ & 10:02 & UFA & $<.080$ & $<.03$ & .051 & .001 & ${ }^{2} .009$ & .011 & $<.006$ & $<.001$ & .002 & $<.002$ & .049 & ${ }^{2} .160$ \\
\hline & & & FA & $<.080$ & $<.03$ & .045 & $<.001$ & ${ }^{2} .004$ & .018 & $<.006$ & $<.001$ & .001 & $<.002$ & .048 & .096 \\
\hline & & & $\mathrm{RA}$ & $<.080$ & $<.03$ & .039 & .001 & $<.001$ & .049 & $<.006$ & $<.001$ & $<.001$ & $<.002$ & .037 & .081 \\
\hline \multirow[t]{3}{*}{4,276} & $S$ & $9: 46$ & UFA & $<.080$ & $<.03$ & .045 & $<.001$ & $<.001$ & .013 & $<.006$ & $<.001$ & $<.001$ & $<.002$ & .046 & .067 \\
\hline & & & FA & $<.080$ & $<.03$ & .050 & .001 & $<.001$ & .021 & $<.006$ & $<.001$ & $<.001$ & $<.002$ & .046 & .084 \\
\hline & & & RA & $<.080$ & $<.03$ & .052 & .002 & $<.001$ & .052 & $<.006$ & $<.001$ & .002 & .002 & .048 & .081 \\
\hline
\end{tabular}


Table 3. Chemical analyses of trace elements in water samples from American Fork, October 1999, and Mary Ellen Gulch, Utah, September 2000.-Continued

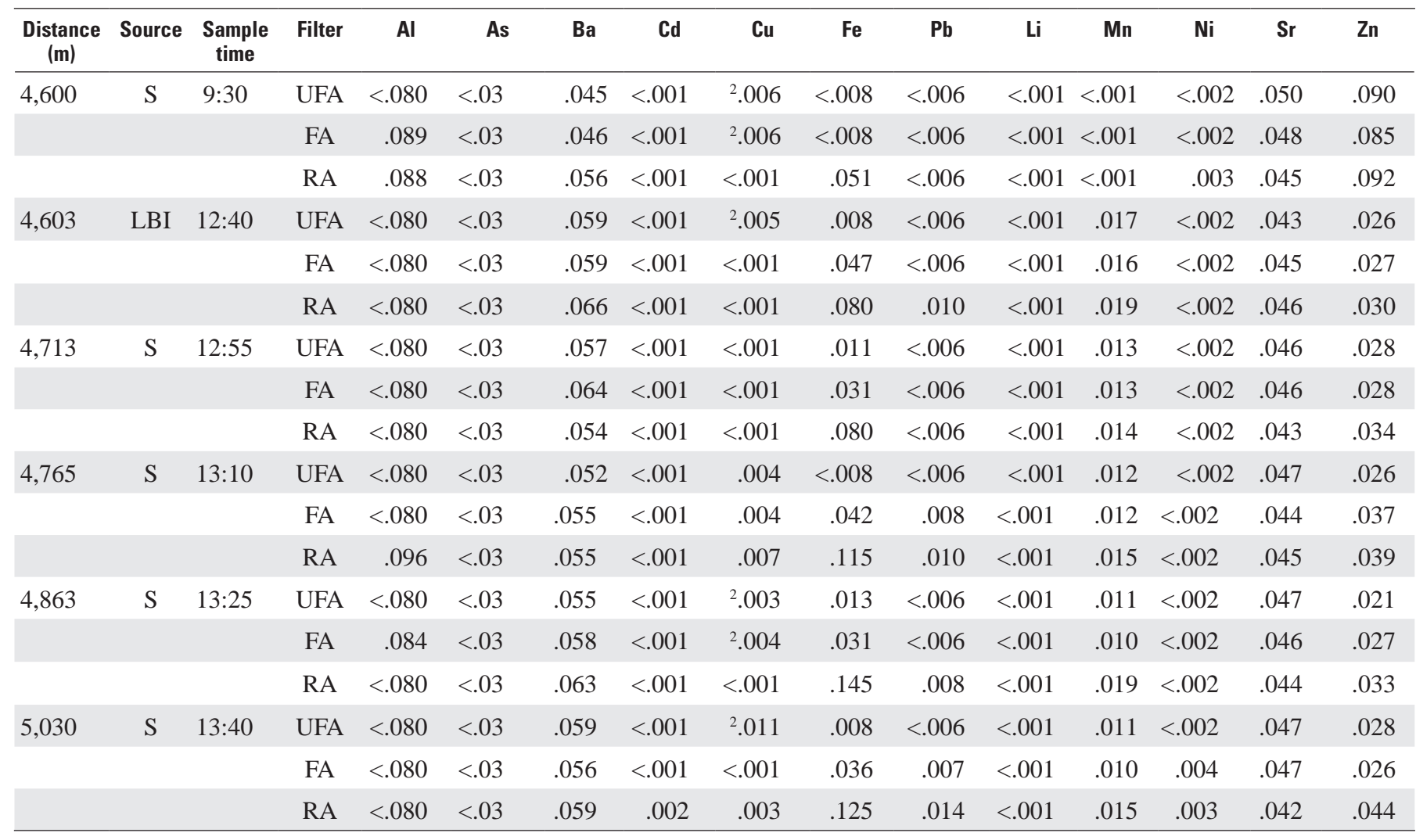

${ }^{1}$ Possible contamination

${ }^{2}$ Contamination, the sample was not used

${ }^{3}$ USGS sample lost in field, used results from a U.S. Forest Service sample

Table 4. Method detection limits and relative standard deviation of quality-assurance samples.

[MDL, method detection limit, in micrograms per liter; $\mathrm{CaCO}_{3}$, calcium carbonate; $\mathrm{NE}$, no equation]

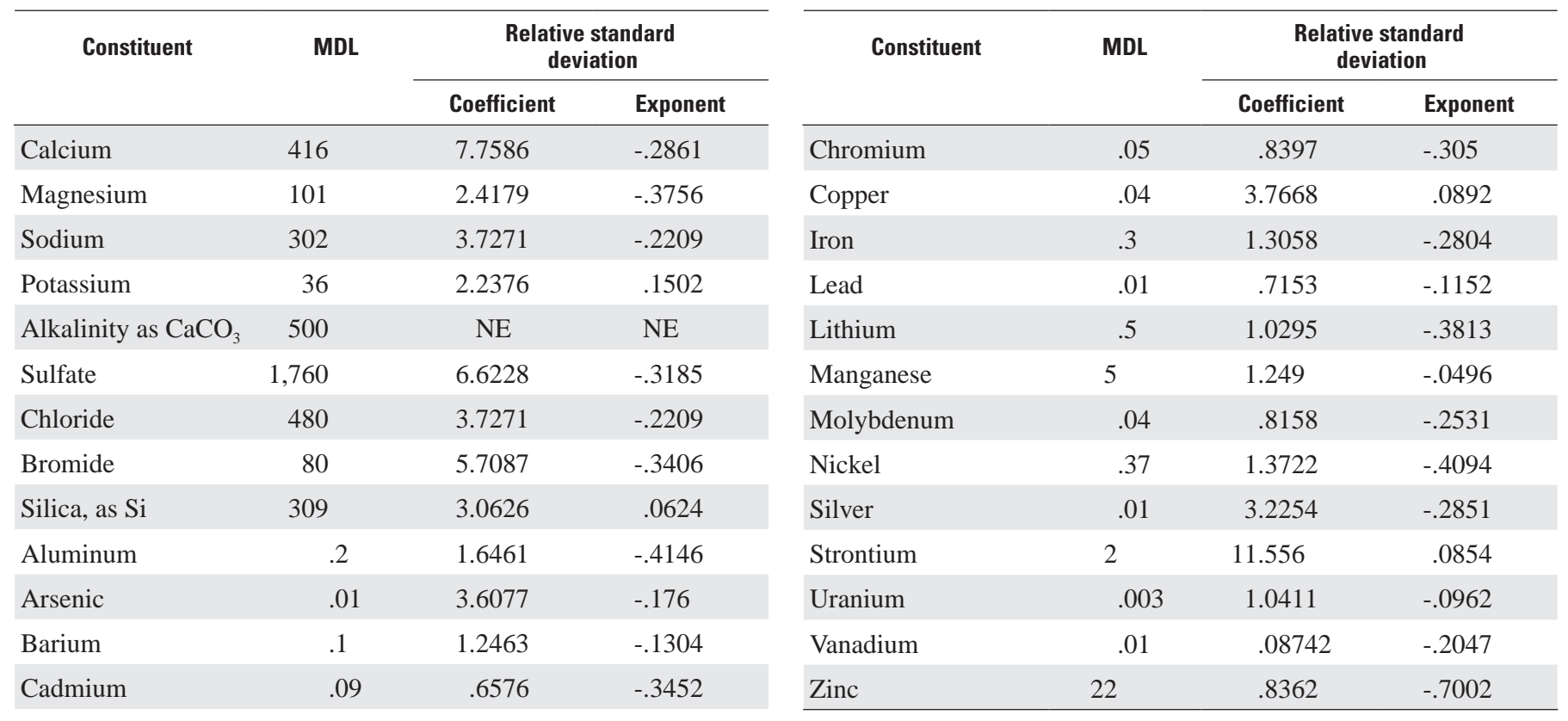

Cobalt

.01

.1594

$-.57$ 

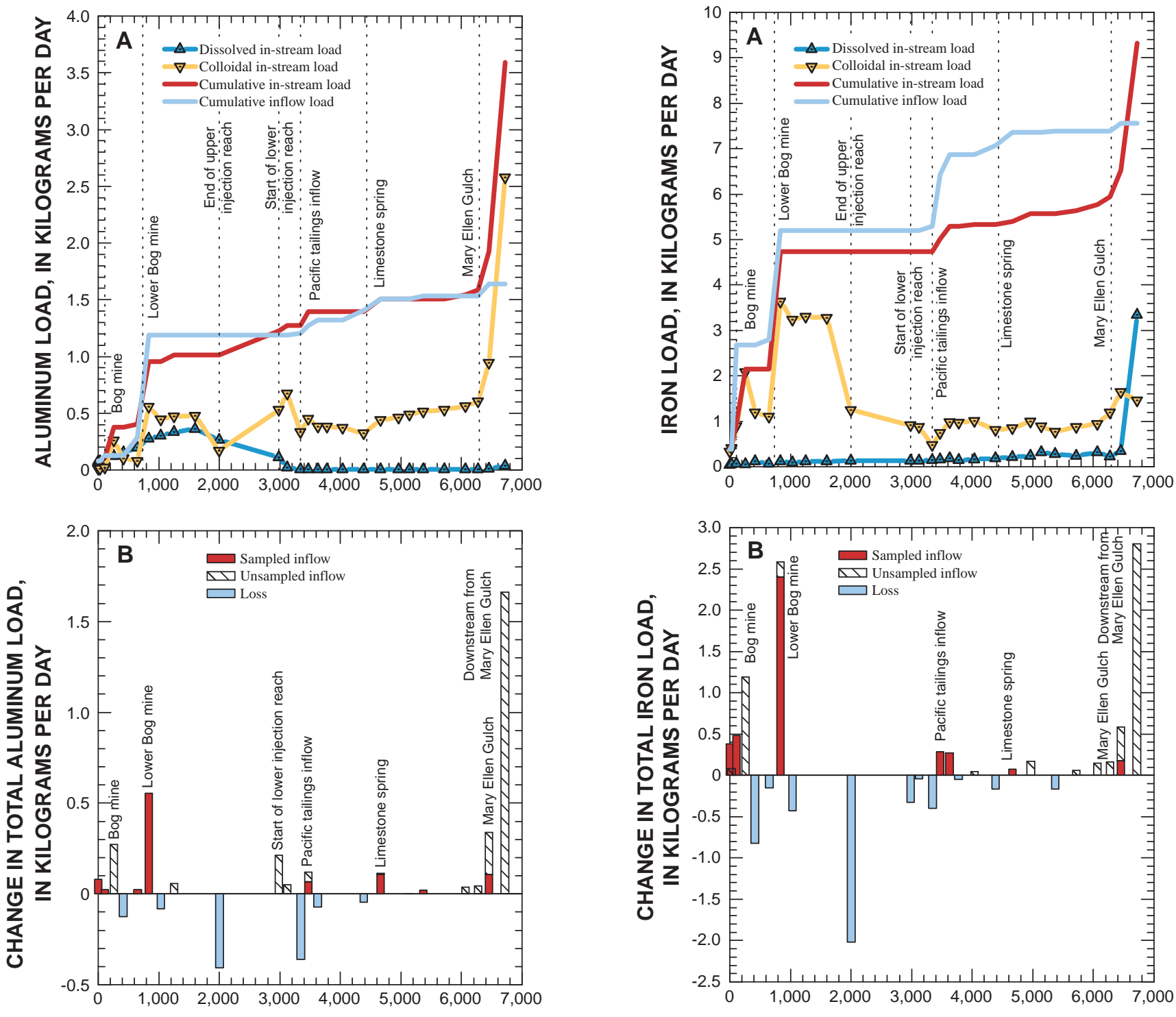

DISTANCE ALONG STUDY REACH, IN METERS

Figure 2. (A) Mass-loading profiles for aluminum and (B) change in aluminum load for individual stream segments, including unsampled inflow load, American Fork, Utah, October 1999.

Figure 3. (A) Mass-loading profiles for iron and (B) change in iron load for individual stream segments, including unsampled inflow load, American Fork, Utah, October 1999. 

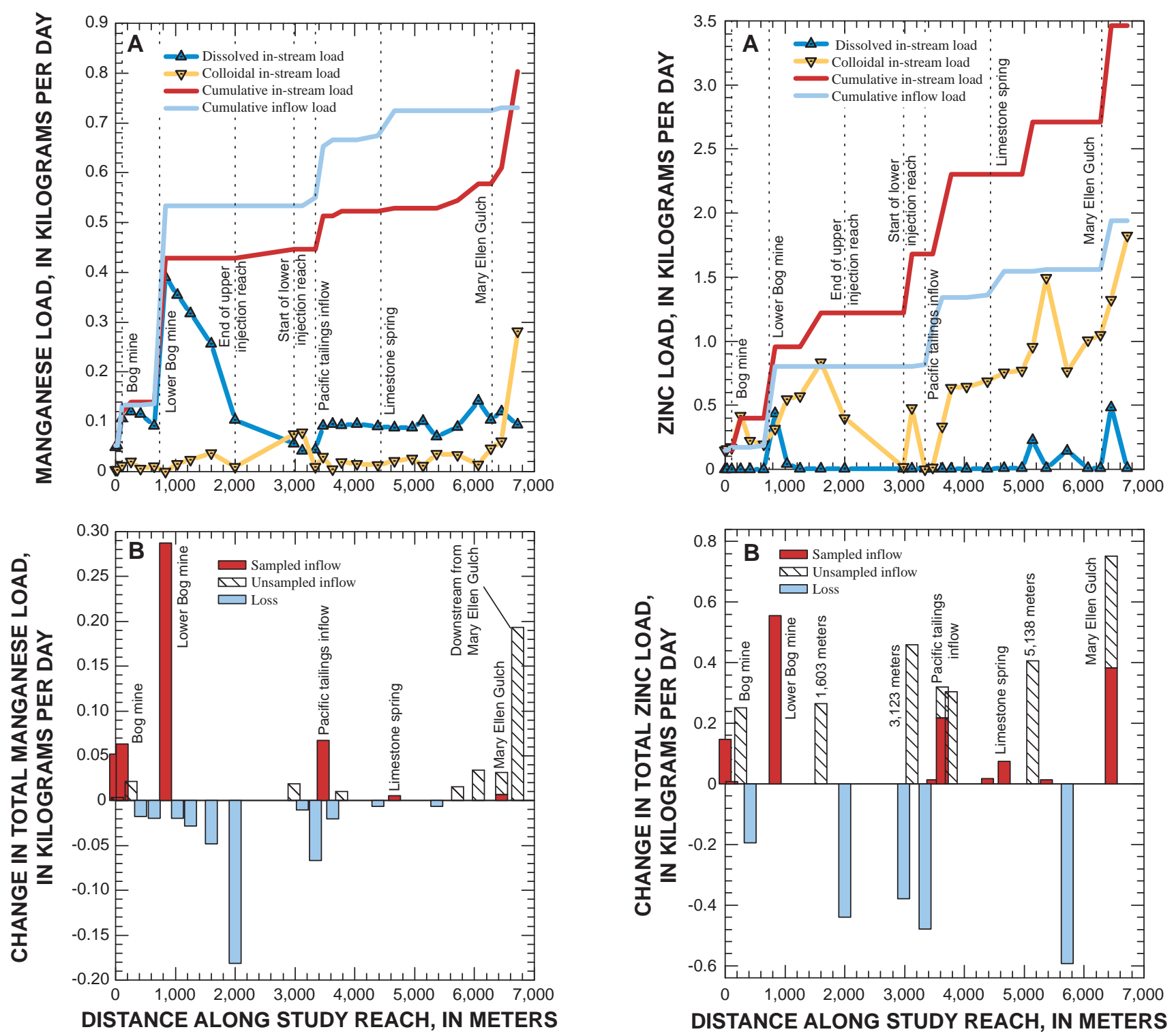

Figure 4. (A) Mass-loading profiles for manganese and (B) change in manganese load for individual stream segments, including unsampled inflow load, American Fork, Utah, October 1999.

Figure 5. (A) Mass-loading profiles for zinc and (B) change in zinc load for individual stream segments, including unsampled inflow load, American Fork, Utah, October 1999. 

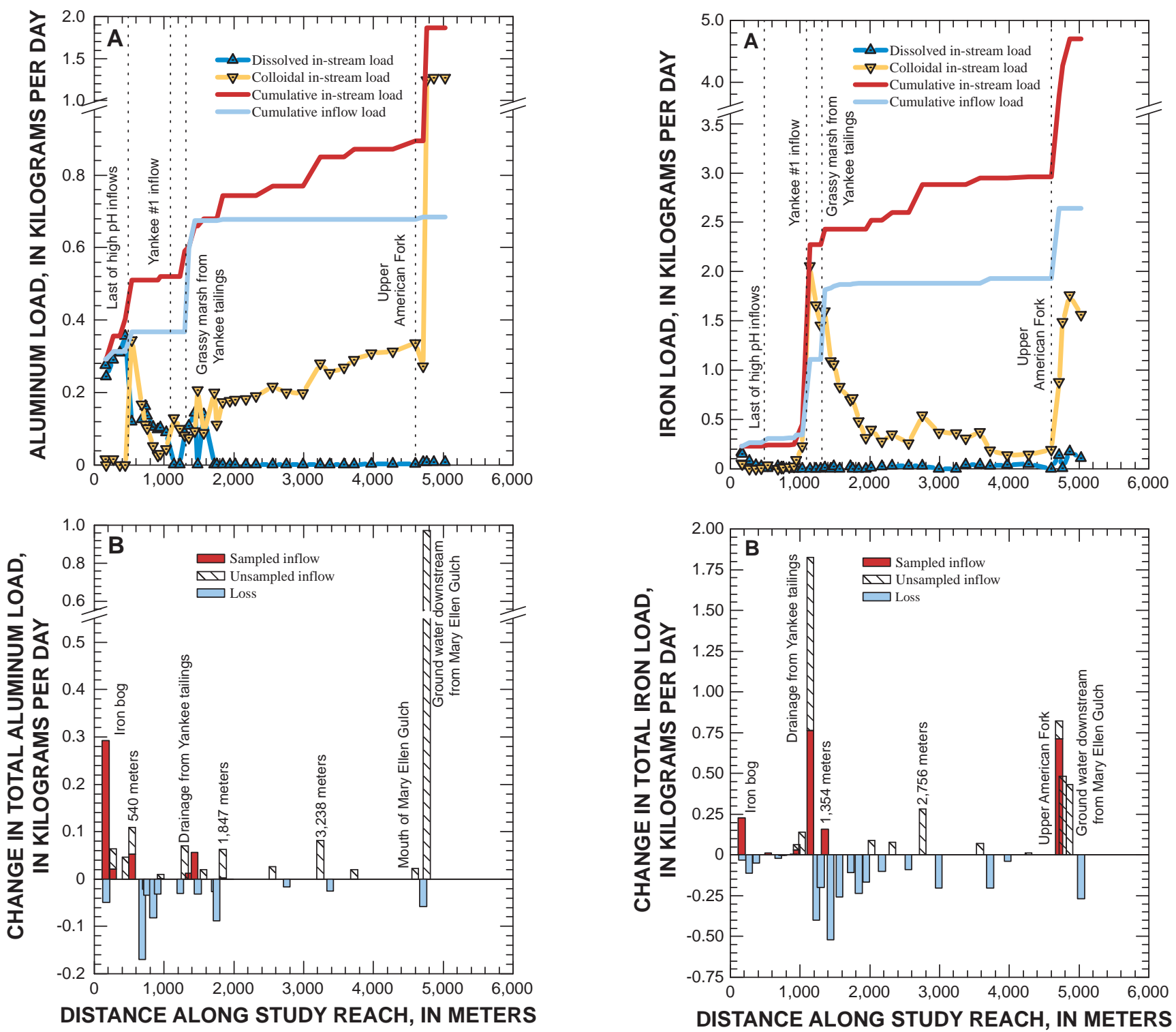

Figure 6. (A) Mass-loading profiles for aluminum and (B) change in aluminum load for individual stream segments, including unsampled inflow load, Mary Ellen Gulch, Utah, September 2000.

Figure 7. (A) Mass-loading profiles for iron and (B) change in iron load for individual stream segments, including unsampled inflow load, Mary Ellen Gulch, Utah, September 2000. 

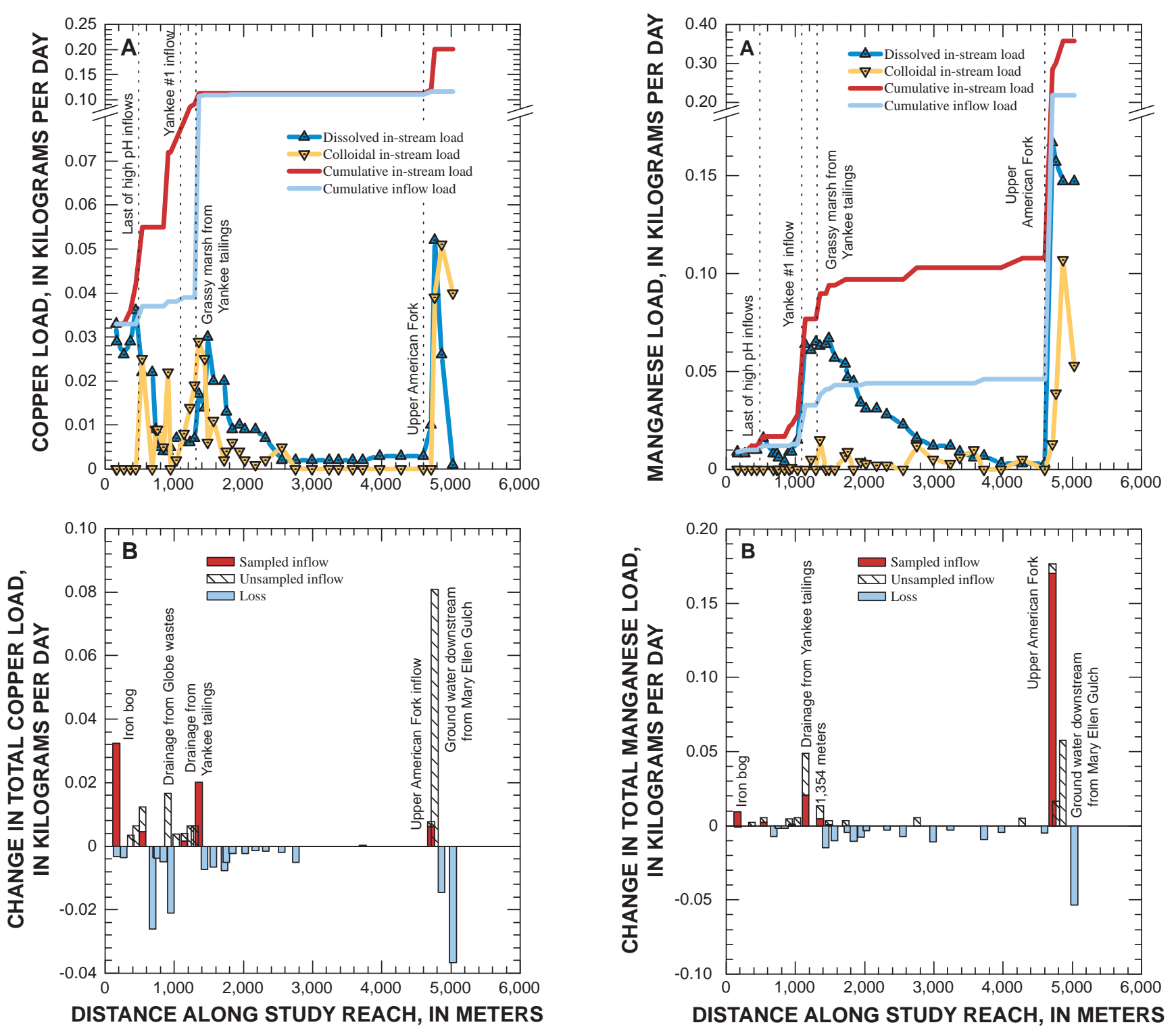

Figure 8. (A) Mass-loading profiles for copper and (B) change in copper load for individual stream segments, including unsampled inflow load, Mary Ellen Gulch, Utah, September 2000.

Figure 9. (A) Mass-loading profiles for manganese and (B) change in manganese load for individual stream segments, including unsampled inflow load, Mary Ellen Gulch, Utah, September 2000. 

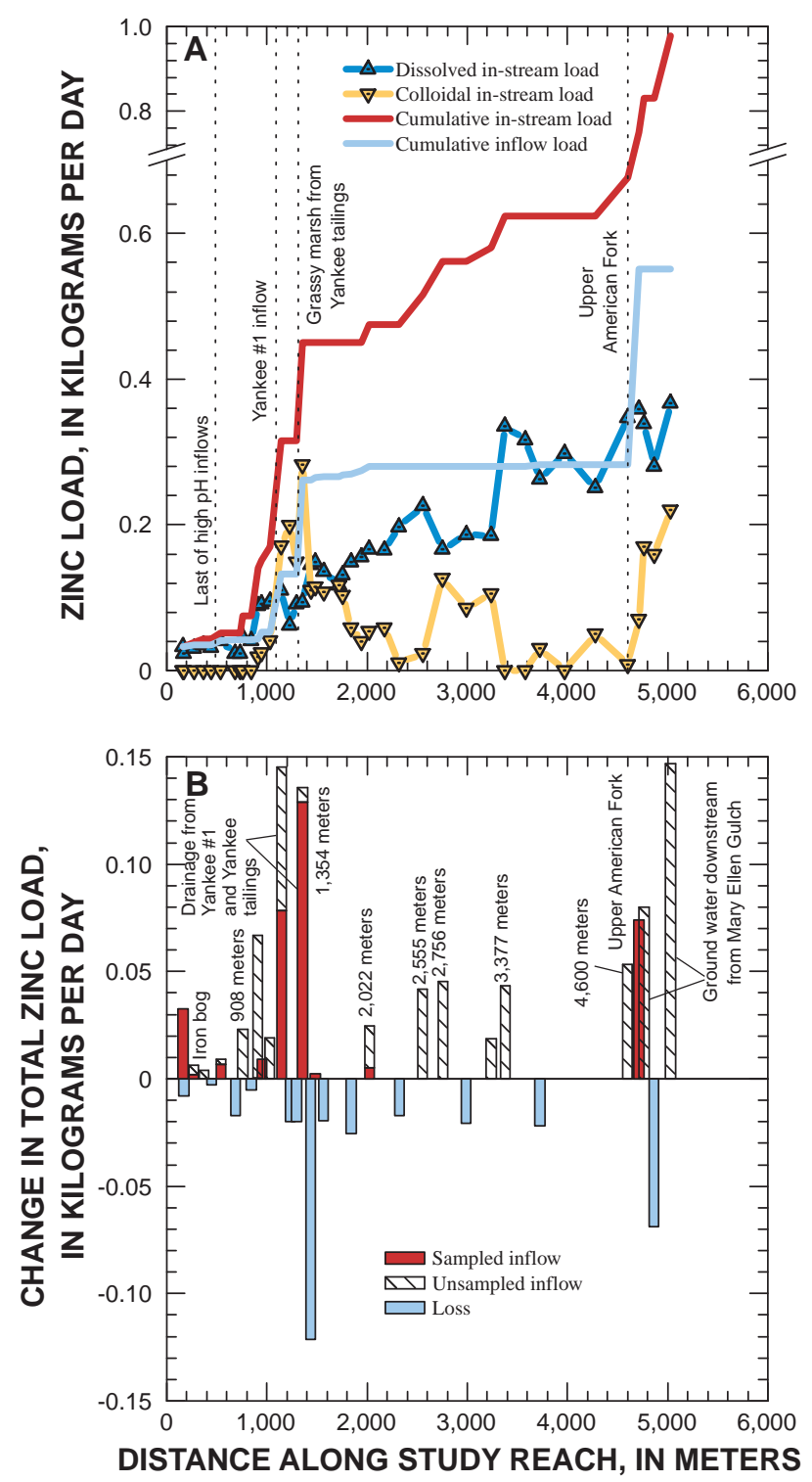

Figure 10. (A) Mass-loading profiles for zinc and (B) change in zinc load for individual stream segments, including unsampled inflow load, Mary Ellen Gulch, Utah, September 2000. 



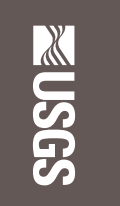

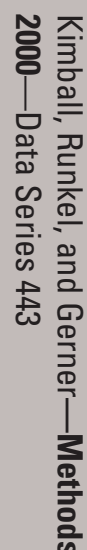

言

总.

뮿

홐

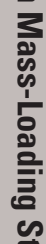

ํㅗำ

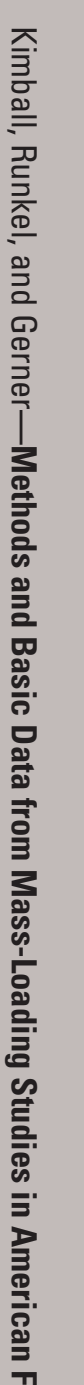

꿏

웅

$\stackrel{\underline{\underline{\sigma}}}{\mathbf{0}}$

¿

言

誉

홀 